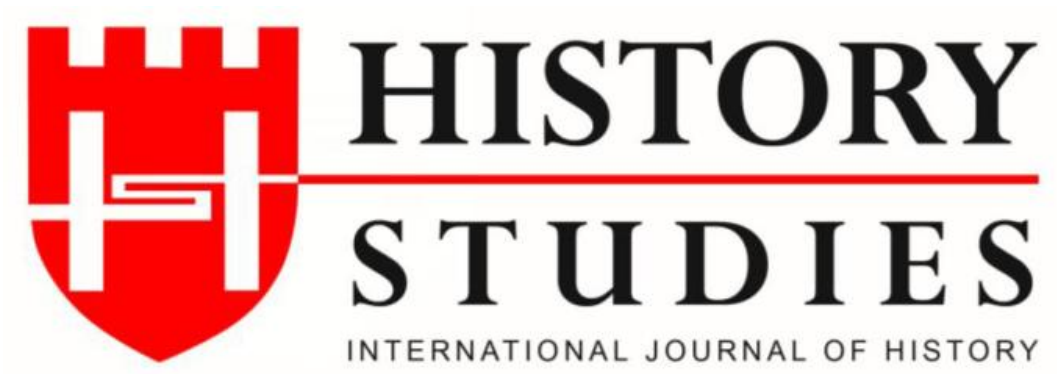

ISSN: 13094173 (Online) 1309 - 4688 (Print)

Volume 11 Issue 1, p. 225-249, February 2019

DOI: $10.9737 /$ hist.2019.715

Makalenin Geliş Tarihi: 13.12.2018 - Kabul Tarihi: 14.01.2019

\title{
Persler /Akhaemenidler Dönemindeki Bölgelerarası Ticari İlişskiler Bağlamında MÖ 6. ve 5. Yüzyıl Sikke Defineleri*
}

The Coin Hoards of 6th and 5th Century B.C: In the Context of Persians/Achaemenids Period Inter-Regional Trade Relations

\author{
Dr. Fariz ÖNCÜ \\ ORCID No: 0000-0002-0759-7968 \\ Dumlupınar Üniversitesi Fen-Edebiyat Fakültesi Tarih Bölümü - Kütahya
}

\begin{abstract}
Öz: Sikkenin MÖ 7. yüzyllın son çeyreğinden itibaren ekonomik ve politik alanda Anadolu'nun batı ve iç batı kesimlerindeki birçok merkez tarafindan kullanıldı̆̆ bilinir. Sikke kullanımına yabancı olan Persler Anadolu'nun egemenliğini MÖ 6. yüzyılın ikinci yarısının başlarında ele geçirdiklerinde, Batı Anadolu'daki sikke üretim ve kullanım alanlarına müdahalede bulunmazlar ve mevcut yapının kendi çıkarları doğrultusunda devam etmesini sağlarlar. Bu noktada, MÖ 6. yüzyıldan MÖ 5. yüzyılın sonlarına kadar istisna olarak kabul edilebilecek tek bir müdahaleden söz edilebilir; bu da Pers kralı I. Dareios 'un Lydia döneminden kalma altın ve gümüss sikkelerin (kroesoid) yerine dareikos (kralın altın sikkeleri) ve sigloslar (kralın gümüşs sikkeleri) darp etmeye başlamasıdır. Ancak Perslerin Anadolu'da egemen oldukları dönemde Anadolu'nun kıyı kesimleri ile Ege ve Batı Akdeniz'deki birçok merkezde sikke ekonomik-ticari bir meta ve değişim aracı olarak oldukça yaygın bir kullanım alanına sahiptir. Dolayısıyla, bu dönemdeki bölgelerarası ekonomik ve ticari iliskilerin nasıl olduğu hususunda sikke buluntuları önemli veriler sunar. Buradan hareketle, çalışmamızda, MÖ 6. ve 5. yüzyllara tarihlendirilen ve farklı bölgelerde bulunan çok savıda seçili sikke definesinin içerik ve bölgesel dağılımı, Perslerin Anadolu'da hâkim gụ̧̈ oldukları dönemdeki bölgelerarası ticari iliş̧kileri farklı bir boyutuyla tartışmak ve anlamak amacıyla yeniden gözden geçirilecektir.
\end{abstract}

Anahtar Kelimeler: Akhaemenidler, Persler, Anadolu, Sikkeler, Ticaret, Ekonomi, IGCH, Sikke Defineleri.

\begin{abstract}
It is known that coins were used by many centers in the western and inner western parts of Anatolia in the economic and political sphere from the last quarter of the 7th century B.C. Persians, who were unfamiliar with the use of coins, took over the sovereignty of Anatolia at the beginning of the second half of the 6th century B.C. During this period, Persians did not intervene in the production and usage areas of coins in Western Anatolia and enabled the existing structure to continue in line with their own interests. From the 6th century B.C to the end of the 5th century B.C the production of the darics (the gold coins of the king) and the sigloi (the silver coins of the king), which Dareios I had begun to mint in the place of the Lydian-era gold and silver coins about 515 B.C, can be regarded as an exception at this point. However, in the period when the Persians dominated Anatolia, the coins were widely used as an economic-commercial commodity and exchange tool in the Aegean, the Western Mediterranean and the coastal regions of Anatolia. Hence, in terms of the 6th and 5th centuries B.C. when the Persians held control over a large part of Anatolia, coin finds provide important data regarding the economic and commercial relations between regions. From this point of view, in this study, the content and regional distribution of a large number of selected coins dated to the 6th and 5th centuries BC will be handled in order to discuss and understand a different dimension of interregional trade relations of the Achaemenid Persian period.
\end{abstract}

Keywords: Achaemenids, Persians, Anatolia, Coins, Trade, Economy, IGCH, Coin Hoards.

\footnotetext{
* Bu çalışma 2018 yılında Ankara Üniversitesi Sosyal Bilimler Enstitüsünde kabul edilen "M.Ö. 6. ve 5. Yüzyıllarda Achaemenid/Pers İmparatorluğu Yönetiminde Anadolu'da Ekonomik Durum” başlıklı doktora tezimden türetilmiştir.
} 


\section{Giriş}

Persler, Kral II. Kyros'un (MÖ yak. 559-530) komutasında MÖ 547'de Lydia kralı Kroisos'u yenerek neredeyse Anadolu'nun tamamı üzerinde egemenlik kurmayı başarırlar. ${ }^{1}$ Perslerin Anadolu coğrafyası üzerindeki hükümranlığı iki asırdan fazla (MÖ yak. 547-330) devam eder. Bu dönem Anadolu'nun farklı özelliklere sahip bölgeleri için idari ve politik alanda olduğu gibi, ekonomik alanda da "yeni" bir sürecin başlangıcı olur. Bu noktada, satraplık çerçevesinde kimlik kazanan Anadolu'daki Pers idare sisteminin temel iki özelliğinden bahsetmek gerekir; bunlardan birincisi, Perslerin fethettikleri bölgelerde, yerel ihtiyaçları göz önüne alarak mevcut yapıların devamı yönünde gösterdikleri eğilimdir. İkinci özellik ise, yine ihtiyaç halinde, kendinden önceki uygulamaların değişimi doğrultusunda gösterilen tutumdur. Bölgesel ihtiyaçları dikkate alan Pers idaresinin bu esnek yapısına ${ }^{2}$, Anadolu'nun kıyı kesimlerindeki sikke üretim ve kullanım faaliyetleri üzerinden de şahit olunur. Bilim insanları arasında mutabık kalınmamış bir tartışma konusu olsa $\mathrm{da}^{3}$, ilk sikkelerin elektron sikke olarak Pers egemenliğinden yaklaşık 60 yıl önce Lydia tahtına geçen Alyattes (MÖ yak. 610-560) tarafından darp edildiği kabul edilir. ${ }^{4}$ Ephesos'taki Artemis Tapınağı'nda, D. G. Hogarth başkanlığında 1904-5 tarihinde yürütülen kazı çalışmaları, birçok Hellen polisinin de Lydia döneminden itibaren elektron sikke üretim faaliyetleri içinde olduğunu gösterir. ${ }^{5}$ Anadolu'nun batı kıyı ve iç kesimlerinde elektron sikke üzerinden şekillenen para sistemi, Lydia'nın Karun olarak da bilinen ünlü kralı Kroisos dönemine (MÖ yak. 560-547 ) kadar varlığını devam ettirir. Bundan sonraki süreçte ise, elektron sikkelerin yerine saf altın ve saf gümüş sikkeler (kroesoid) ${ }^{6}$ darp edilmeye başlanır. ${ }^{7}$ Bu durum sikke üretiminin eski dünyada yayılmasında önemli bir rol oynar. ${ }^{8}$ Aynı dönemlerde Anadolu'nun batı kıyılarında bulunan bazı Hellen polislerinin de gümüş sikke darbına başladıkları görülür. ${ }^{9}$

Pers kralları MÖ 547'den sonra Anadolu'da hâkimiyet kurmaya başladıklarında, sikke üretim ve kullanımı noktasında Anadolu'nun batı kesimlerinde böyle bir miras devralırlar. Yeni egemenler, yönetimlerinin yaklaşık ilk çeyrek asırlık döneminde mevcut sikke üretim

\footnotetext{
${ }^{1}$ Hdt. I. 69-86.

${ }^{2}$ Elspeth R. M. Dusinberre, Aspects of Empire in Achaemenid Sardis, Cambridge University Press, Cambridge 2003, s. 1

${ }^{3}$ Christopher Howgego, Sikkelerin Işı̆̆ında Eskiçağ Tarihi, Çev: Oğuz Tekin, Homer Kitabevi, İstanbul 2013, s. 17.

${ }^{4}$ Jack M. Balcer, "The East Greeks Under Persian Rule: A Reassessment", Achaemenid History VI, Leiden 1991, s. 58; G.K. Jenkins, Ancient Greek Coins, London 1990, s. 13; Colin M. Kraay, Archaic and Classical Greek Coins, New York 1976, s. 24; Georges L. Rider, La Naissance de la Monnaie: Pratiques Monétaires de I'Orient Ancien, Presses Universitaires de France, Paris 2001, s. XIII, 41; Oğuz Tekin, Eski Yunan ve Roma Tarihine Giriş, İletişim Yayınlar1, İstanbul 2010, s. 87-88.

${ }^{5}$ I. Carradice - M. Price, Helen Dünyasında Sikke, Homer Kitabevi, Çev: Oğuz Tekin, İstanbul 2001, s. 18-19; D. G. Hogarth, Excavations at Ephesus, London 1908; Howgego, 2013, s. 18-21; Jenkins, 1990, s. 13; Kraay, 1976, s. 21-22; Oğuz Tekin, Antik Nümismatik ve Anadolu (Arkaik ve Klasik Çağlar), Arkeoloji ve Sanat Yayınları, İstanbul 2008, s. 54-55.

${ }^{6}$ Kroisos döneminde darp edilmeye başlayan kroesoidler (Lydia kralının saf altın ve saf gümüş sikkeleri), önyüzü aslan ve boğa protomlarının karş1lıklı durduğu standart bir tiple tasvir edilir. Örnekler için bkz. Fariz Öncü, M.Ö. 6 . ve 5. Yüzyıllarda Achaemenid/Pers Imparatorluğu Yönetiminde Anadolu'da Ekonomik Durum, (Yayımlanmamış Doktora Tezi), Anakara Üniversitesi Sosyal Bilimler Enstitüsü, Ankara 2018, Levha I, No. 1-2. Altın kroesoid staterlerinin ağırlığı üretimlerinin ilk dönemlerinde 10.90 gram iken, daha sonra bu ağırlık 8.10 grama düşürülür. Gümüş kroesoid staterlerinin ağırlı̆̆ ise 10.90 gramdır. Bkz. Koray Konuk, Karun'dan Karia'ya. Muharrem Kayhan Koleksiyonundan Erken Anadolu Sikkeleri, Ege Yayınları, İstanbul 2003, s. 47.

${ }^{7}$ Michael Alram, "The Coinage of the Persian Empire", The Oxford Handbook of Greek and Roman Coinage, Ed. William E. Metcalf, Oxford University Press, Oxford 2012, s. 62; Jenkins, 1990, s. 20; Konuk, 2003, s. 41; Kraay, 1976, s. 30-31.

${ }^{8}$ Konuk, 2003, s. 41.

${ }^{9}$ Balcer, 1991, s. 59; Tekin, 2008, s. 61.
} 
faaliyetlerine bir müdahalede bulunmazlar. ${ }^{10}$ Başka bir ifadeyle, sikkenin ekonomik ve politik kullanımına yabancı olan Persler ${ }^{11}$, hem Kyros hem de Kambyses (MÖ yak. 530-522) dönemlerinde Sardeis'te altın ve gümüş kroesoidlerin üretimini devam ettirirler. ${ }^{12}$ Yine, Anadolu'nun kıyı bölgelerindeki Hellen polisleri de Perslerin hâkimiyetinde, üzerinde kendi bölgelerini tanıtan tiplerin ve lejantların yer aldığı sikkeleri darp etmeyi sürdürürler. ${ }^{13}$

Mevcut sikke üretim geleneğine müdahalede bulunan ilk Pers kralı ise, bir yönetim darbesiyle tahta geçen ${ }^{14}$ I. Dareios (MÖ yak. 522-486) olur. I. Dareios'un hükümdarlığının ilk dönemlerinde kroesoidler yerine, Plutarkhos'un ${ }^{15}$ üzerindeki tasvirlerden dolayı To gó $\tau \alpha 1 /^{2}$ toksotai $=$ Okçular olarak bahsettiği kralın dareikos denilen altın sikkeleriyle siglos olarak adlandırılan gümüş sikkeleri darp edilmeye başlanır. ${ }^{16}$ Ancak bu dönemde Anadolu'nun kıyı kesimlerindeki yerleşimlerin ve yerel unsurların (örneğin Hellen polisleri) kendi özelliklerine uygun olarak gerçekleştirdikleri gümüş sikke darbı ve kullanımı giderek daha yaygın bir faaliyet alanı kazanır. ${ }^{17} \mathrm{Bu}$ durum, aynı zamanda, gümüş sikke kullanımının Akdeniz ve Ege dünyasındaki yaygın dağılımıyla da koşutluk gösterir. Özellikle gümüş sikke, MÖ 6. yüzyılın sonlarına gelindiğinde, Hellas, Sicilya, Güney İtalya, Kyrenaika ve Anadolu'nun Perslerin egemenliğindeki çok sayıda iç ve kıyı bölge yerleşiminde yaygın olarak kullanılır ${ }^{18}$. Sikke kullanımının yaygınlaşmasında ise, başta ticaret olmak üzere ekonomik etkenlerin önemli bir rolü vardır. ${ }^{19}$ Bu bağlamda, değişik bölgelerde ele geçen ve farklı dönemlere atfedilen sikke definelerinin içerikleri ve coğrafi dağılımları, bölgelerarası ekonomik ilişkilerin açıklanmasında önemli veriler sunar. Dolayısıyla, Perslerin Anadolu'da egemen oldukları MÖ 6. yüzyılın sonları ile MÖ 5. yüzyıla tarihlendirilen ve imparatorluğun farklı bölgelerinde ele geçen sikke defineleri, bu bağlamda yapılacak tartışmalar için büyük bir öneme sahiptir. Ancak söz konusu dönemdeki sikke definelerini bölgelerarası ekonomik-ticari ilişkiler çerçevesinde ele alan kapsamlı bir çalışmanın varlı̆̆ından söz edilemez. Bu yüzden, çalışmamızda, MÖ 6. yüzyılın sonları ile MÖ 5. yüzyıla tarihlenen ve Anadolu, Mısır, Suriye, Yunanistan, Makedonya ve İtalya'daki çeşitli merkezlerde bulunan seçili sikke definelerinin ${ }^{20}$

\footnotetext{
${ }^{10}$ Balcer, a.g.m., s. 59.

${ }^{11}$ Oğuz Tekin, "Pers Döneminde Anadolu'da Para ve Ticaret", İçinde: Persler. Anadolu'da Kudret ve Görkem, Ed. K. İren-Ç. Karaöz-Ö. Kasar, Yapı Kredi Yayınları, 2017, s. 102; Christopher Tuplin, "The Changing Pattern of Achaemenid Persian Royal Coinage", Ed. P. Bernholz and R. Vaubel, Explaining Monetary and Financial Innovation, Financial and Monetary Policy Studies 39, DOI: 10.1007/978-3-319-06109-2-6, C Springer International Publishing Switzerland, 2014, s. 127.

${ }^{12}$ Kraay, 1976, s. 31; Rider, 2001, s. 123; Tekin, 2008, s. 71; Tuplin, a.g.m., s. 135.

${ }^{13}$ Balcer, 1991, s. 59).

${ }^{14}$ Hdt. III. 61-88; R. G. Kent, Old Persian: Grammar, Texts, Lexion, American Oriental Society, New Haven 1953, s. 120-134 (DB I, 72-96; DB II, 1-98; DB III, 1-92; DB IV, 1-54; DB V, 1-75).

${ }^{15}$ Plut. Artak. XX. 4; Rider, 2001, s. 123.

${ }^{16}$ Pers krallarının saray giysileri içinde ve mazgalı bir taçla tasvir edildikleri siglos ve dareikoslar ortak bir ikonografiye sahipler. Sikke üzerindeki tasvirlerin tarihsel süreç içinde geçirdikleri küçük değişimler, bilim insanlarının bu sikkeleri kabaca dört tip (Tip I-II-III-IV) halinde ele almalarına sebep olur. Fakat tarihsel süreç içinde görülen küçük değişimlere rağmen, dareikosların ağırlığı yaklaşık 8. 40 gram iken, siglosların ağırlığı yaklaşık olarak 5. 40 gramdır. Ayrıntılı bilgi için bkz. Konuk, 2003, s. 49; Kraay, 1976, s. 32-33; Rider, 2001, s. 128-133; Tekin, 2008, s. 72; Tuplin, 2014, 137-138. Değişik tipteki kral sikkeleriyle ilgili örnekler için ayrıca bkz. Öncü, 2018, Levha I, No. 3-6.

${ }^{17}$ Konuk, 2003, s. 51.

${ }^{18}$ Carradice - Price, 2001, s. 26-45; Howgego, 2013, s. 21; Tekin, 2008, s. 61.

${ }^{19}$ Balcer, 1991, s. 58; Kutalmış Görkay, Batı Anadolu'ya Korinth ve Attika Siyah Figür Seramiğinin İthali, Dă̆ıllımı ve Değerlendirmesi, (Yayımlanmamış Doktora Tezi), Ankara Üniversitesi, Ankara 1999, s. 195).

${ }^{20}$ Çalışmada geçen definelerin isimleri ve tablolardaki numaraları M. Thompson, O. Mørkholm ve C.M. Kraay’ın editörlüğünü yaptıkları Inventory of Greek Coin Hoards (IGCH) adlı eserde geçtiği şekliyle kullanılmıştır. Bkz. M. Thompson - O. Mørkholm- C.M. Kraay, Inventory of Greek Coin Hoards, The American Numismatic Society, New York 1973.
} 
içerikleri, Perslerin Anadolu egemenliği sırasındaki bölgelerarası ticari ilişkilerin farklı bir boyutuyla tartışmaya açılması ve anlaşılması amacıyla ele alınacaktır.

\section{Sikkenin Bölgelerarası Dolaşımında Rol Oynayan Etkenler Üzerine}

MÖ 6. ve 5. yüzyıllara tarihlendirilen sikke definelerinin coğrafik dağılımının çeşitliliği ve yaygınlığı, bu sikkelerin bölgelerarası dolaşımında rol oynayan ticari etkenler dışındaki muhtemel bazı faktörleri de dikkate almayı zorunla kılar. Sikkenin hem ekonomik hem de sosyo-politik olarak antik devletler tarafından kullanılan bir araç olduğu söylenebilir. Dolayısıyla, sikkenin üretimi ve bölgelerarası dolaşımında, devletlerarası ödemelerin, verginin nakdi olarak toplanmasının, askeri masrafların temininin, paralı askerlerin maaş ödemelerinin, armağan olarak farklı sosyo-politik kesimlere sunulmasının etkili olduğu geniş bir yelpazeden söz etmek mümkündür. ${ }^{21}$

Sikkenin bölgelerarası dolaşımında devletlerin olduğu kadar bireylerin de rolü vardır. Örneğin, ticaretle uğraşan bireyler, mal alım satımı, liman ve gümrük geçişlerinde kullanmak için yanlarında sikke taşımış olabilirler. Ya da ücretli askerler, özel harcamaları için yanlarında sikke bulundurabilirler. Yine, küçük birimlerde darp edilen ve metal değeri düşük sikkeler, büyük olasılıkla bireylerin bozuk para olarak yanlarında taşıyı başka yerlerde kaybettikleri paralardır. ${ }^{22}$ Bunların yanı sıra, yabancı sikkeleri dış ticaret etkinliklerindeki acil durumlarda külçe formunda kullanmak üzere saklayan stokçuların da sikke dolaşımındaki etkisinden bahsedilebilir. ${ }^{23}$ Aynı şekilde, söz konusu dönemlerde, karşılıklı mal takasıyla yapılan ticari işlemlerin yaygın olduğunu da dikkatten kaçırmamak gerekir. Başka bir ifadeyle, bu dönemde devam eden ve takas usulüyle gerçekleşen ticari işlemlerde sikkeye ihtiyaç olmayacağından, bir bölgede üretilen sikkelerin başka bir bölgede ele geçmemesi her zaman o bölgeler arasında ticari münasebetlerin olmayacağı anlamına gelmez. ${ }^{24}$ Dolayısıyla, sikkelerin bölgelerarası dağılımıyla bölgelerarası ticari ilişkiler arasındaki bağlantıyı kurarken, bütün bu ve benzeri faktörleri göz önüne alacak dikkatli bir yaklaşım sergilemek gerekir. Bu çerçevede yapılacak analizleri tartışmalı hale getiren bütün bu etkenlere rağmen, sikkenin hem değişim aracı hem de ticari meta olarak bölgelerarası ticari etkinliklerde kullanıldığı bilinir ${ }^{25}$. Önemli ticari değișimlerde, özellikle, değerli metalden darp edilmiş sikke kullanımının ișlevsel olduğu söylenebilir. ${ }^{26}$ Aynı şekilde, MÖ 6. yüzyılın ikinci yarısıyla birlikte yaygınlaşan farklı birimlerdeki gümüş sikkelerin üretim ve dağılımında ticari faaliyetlerin önemli bir etkisi vardır. ${ }^{27}$ Aigina'nın, gümüş kaynaklarına sahip olmadığı halde MÖ 6. ve 5. yüzyıllarda ticari aktiviteleriyle öne çıkması $^{28}$ ve kendisine ait sikke ağıllı sisteminin (12,2 gramlık stater)

\footnotetext{
${ }^{21}$ Howgego, 2013, s. 117.

${ }^{22}$ Howgego, a.g.e., 117-121.

${ }^{23}$ Thomas Figueira, The Power of Money: Coinage and Politics in the Athenian Empire, University of Pennsylvania Press, Philadelphia 1998, s. 25.

${ }^{24}$ Khios bu duruma gösterilebilecek en çarpıcı örneklerden biridir; gerek Anadolu ve Karadeniz'in gerekse Akdeniz'in birçok merkezinde, Khios'a ait çok sayıda ticari amfora buluntusu ele geçer. Bkz. Öncü, 2018, s. 171179. Ancak Khios üretimi sikkelerin dağılımı Khios'un ticari amfora buluntularının dağılımıyla paralellik göstermez. Bkz. Howgego, 2013, s. 121. Bu da muhtemelen Khios'un bölgelerarası ticari işlemlerde yaygın olarak sikkeyi bir değişim aracı olarak kullanılmamasıyla ilgili olmalıdır.

${ }^{25}$ Balcer, 1991, s. 58; Carradice - Price, 2001, s. 53-55; Görkay, 1999, s. 195; Howgego, 2013, s. 118.

${ }^{26}$ F. Bodenstedt, Phokäisches Elektron-Geld, von 600-326 v. Chr., Mainz 1976, s. 74; Figueira, a.g.e., s. 42-43; Howgego, 2013, s. 23.

${ }^{27}$ Howgego, a.g.e., s. 113,120 .

${ }^{28}$ Carradice-Price, a.g.e., s. 50.
} 
birçok farklı merkezde yaygın olarak kullanılması, bu bağlamda gösterilebilecek en açıklayıcı örnekler arasındadır ${ }^{29}$.

\section{Sikke Definelerinin Bölgelerarası Ticari İlişkiler Açısından Değerlendirmeleri}

\subsection{Ras Samra Definesi (IGCH 1478)}

MÖ 6. yüzyılın son dönemlerinde Pers egemenliğinde olan Thrako-Makedonya'daki merkezlerle Akdeniz'in doğu kesimleri arasındaki ekonomik ilişkiler hakkında veri sunan önemli definelerden biri, gömü tarihinin MÖ yaklaşı 525-520 ya da 510-500 dönemleri arasında olduğu düşünülen ve Suriye'de bulunan Ras Samra Definesi'dir (IGCH 1478). Aşağıda tabloyla (Tablo 1) da gösterildiği üzere, Ras Samra Definesi'nde toplam otuz dokuz gümüş sikke ele geçer. Kıbrıs üretimi altı sikke dışında kalan sikkelerin neredeyse tamamı (otuz iki adet) Thrakia-Makedonya’nın değişik merkezlerinin üretimleridir.

Tablo 1: Ras Samra Sikke Definesi ve Define İçeriğinin Bölgesel Dağılımı

\begin{tabular}{|c|c|c|c|c|c|}
\hline y) & Definenin Adı & $\begin{array}{c}\text { Definenin } \\
\text { Bulunduğu Yer }\end{array}$ & Gömü Tarihi & $\begin{array}{c}\text { Definedeki } \\
\text { Sikkelerin } \\
\text { Toplam } \\
\text { Miktarı ve } \\
\text { Cinsi }\end{array}$ & $\begin{array}{l}\text { Definede Sikkeleri Bulunan } \\
\text { Kentler ve Sikkelerin Dağılımı }\end{array}$ \\
\hline STUDIES & & & & & Stagira 4 st - Abdera 1 tetradr. \\
\hline $\begin{array}{l}229 \\
\text { Volume } 11\end{array}$ & IGCH 1478 & $\begin{array}{c}\text { Ras Samra (Ugarit) } \\
\text { Suriye. }\end{array}$ & $\begin{array}{c}\text { MÖ yak. 525- } \\
520\end{array}$ & $39 \mathrm{AR}$ & $\begin{array}{l}\text { Lete?: } 12 \text { st.; Bilinmeyen. } \\
\text { Maced.: } 14 \text { st. Bilinmeyen } \\
\text { Thraco-Maced.: } 1 \text { st.; Kıbris: } 6 \\
\text { st.; Bilinmeyen darphane: } 1 \text { st. }\end{array}$ \\
\hline
\end{tabular}

\footnotetext{
${ }^{29}$ Sikke kaynaklarına ulaşma imkânlarının çapı, devletlerin sikke darp etme faaliyetleri üzerinde belirleyici bir etkiye sahiptir. Bkz. Carradice - Price, a.g.e., s. 49. Tmolos (Bozdağlar) dağı ve Paktolos Irmağı'nın elektron, altın ve gümüş madenlerinin Sardeis'e (Hdt. V. 101;A. Ramage - N. H. Ramage, Twenty-Five Years of Discovery at Sardis 1958- 1983, United States of America: The National Endowment for the Humanities, 1983, s. 7; A. Ramage, "Golden Sardis", Ed. A. Ramage and P.T. Craddock, King Croesus' Gold, London, British Museum Press, 2000, s. 19; M. A. Dandamaev - V. G. Lukonin, The Culture and Social Institutions of Ancient Iran, Cambridge University Press, Cambridge 1989, s. 21), Lauron gümüş kaynaklarının Atina'ya (Howgego, 2013, s. 42), Siphnos Adası'nın altın madenlerinin Thasos ve Lamsakos'a ( Carradice - Price, 2001, s. 49) bu açıdan önemli katkı sağlamıştır. Ancak sikke darbı için gereken bu imkânlara Aigina sahip değildir. Arazinin kayalık yapısı nedeniyle tarıma elverişli alanlarının da az olduğu Aigina (Kraay, 1976, s. 42), yine de, gerek kendine ait ağırlık sistemiyle ürettiği gümüş sikkeleri (Carradice-Price, a.g.e., 50; Tekin, 2008, s. 35) gerekse zenginliğiyle MÖ 6. ve 5. yüzyıllarda öne çıkan merkezler arasında yer alır. Zenginliğini, Karadeniz'den Doğu Akdeniz'e kadar olan bölgelerarası ticari faaliyetlerdeki etkin varlığına borçlu olan Aigina (Görkay, 1999, s. 197; Hdt. II. 178-179; IV. 152; VII. 147. 2; Kraay, a.g.e., s. 42), sikke üretimi için muhtemelen bölgelerarası dolaşımda olan metallerden yararlanır (CarradicePrice, a.g.e., s. 50). Bu ticari faaliyetler, aynı zamanda, sikke üretiminde Aigina ağırlık sisteminin Güney Ege, Akdeniz (Balcer, 1991, s. 59), Karadeniz ve Batı Anadolu'nun birçok merkezinde benimsenmesine sebep olur. Pers egemenliği döneminde, bölgelerarası ticaretin gelişimini de gösteren ve Aigina ağırlık sisteminde sikke darp ettiğ bilinen Anadolu'nun kıyı kesimlerindeki önemli merkezler arasında Teos (Balcer, a.g.m., s. 59; Öncü, 2018, Levha IV, No. 91-98), Phokaia (Balcer, a.g.m., s. 60-61; Bodenstedt, 1976, s. 56, 90; Öncü, a.g.e., Levha IV, No. 72-79), Sinope ( A. Avram- J. Hind - G. Tsetskhladze, "Black Sea Area", An Inventory of Archaic and Classical Poleis, Ed. M.H.Hansen-T.H.Nielsen, Oxford University Press, New York 2004, 2004, s. 963; Kraay, a.g.e., s. 245; Öncü, a.g.e., Levha V, No. 99-102) ve Aphrodisias (J. D. Bing, A History of Kilikia During the Assyrian Period, Indiana University, Ph.D., Michigan 1968, s. 157; B. V. Head, Historia Numorum: A Manual of Greek Numismatics, Oxford 1911, s. 717) yer alır. MÖ 5. yüzyılın ilk dönemlerinden başlayarak Batı Anadolu'da başka yerleşimlerin de Aigina ağırlık sisteminde sikke darp ettikleriyle ilgili olarak bkz. S. E. Psoma, "Choosing and Changing Monetary Standarts in the Greek World During the Archaic and Classical Periods", Ed. Edward M. Harris, David M. Lewis, Mark Woolmer, The Ancient Greek Ekonomy: Markets, Households and City-States, New York 2016, s. 97.
} 
Definedeki sikkelerin Thrako-Makedon ağırlıklı bölgesel dağılımı, söz konusu bölgeler arasındaki ekonomik ilişkilerin bir göstergesi olarak kabul edilebilir. Ancak bu ilişkinin ticari etkenlerden kaynaklanıp kaynaklanmadığı net değildir. Sikkelerin, imparatorluğun Yakındoğu'daki merkezlerinin büyük bir bölümünde olduğu gibi Suriye'de de sadece külçe olarak işlem görmüş olma ihtimali ${ }^{30}$, bu belirsizliğin sürmesindeki temel etkendir. Başka bir ifadeyle, yaklaşık MÖ 5. yüzyılın ikinci yarısına kadar, Pers egemenliği altındaki Mısır ve Yakındoğu coğrafyasının neredeyse tamamında gümüş sikke külçe olarak ve gerçek değeri üzerinden işlem görür. Bu yüzden, bu bölgedeki ticari faaliyetlerin gerçekleşmesinde değişim aracı olarak gümüşün sikke formunda kullanılması beklenen bir durum değildir. Ancak I. Dareios döneminde gerçekleşen vergi reformunun, bölgelerarası ticari faaliyetler üzerinden sikke dolaşımını tetiklediği düşünülebilir. Herodotos'a göre, I. Dareios, imparatorluğu yirmi vergi bölgesine (arkhai veya nomoi) ayırarak, vergilerin (phoroi) neredeyse tamamını gümüş üzerinden toplamaya başlar ${ }^{31}$. I. Dareios'un gümüş madenlerine ulaşma çabası içinde olduğu, kralın MÖ yaklaşık 513'te zengin maden kaynaklarına sahip Skythia'yı ele geçirmek amacıyla sefere çıkmasından ${ }^{32}$ da anlaşılabilir. Bu dönemde Pers krallarının vergileri gümüş üzerinden toplama zorunluluğu (!) getirmeleri, Doğu Akdeniz'de gümüş madenleri açısından zayıf olan bölgeleri ticari yolla bu madenleri başka bölgelerden temin etme gayretine sokmuş olmalıdır. $\mathrm{Bu}$ noktada, ticaretin, imparatorluğa gümüş olarak ödenmesi gereken verginin sağlayıcısı bir araç olduğu düşünülebilir. Dolayısıyla, Ras Samra Definesi’ndeki Thrako-Makedonya üretimi ağırlıklı sikkelerin temsilinde, Doğu Akdeniz'deki yerleşimlerin gümüş ihtiyaçlarını ticari faaliyetlerle karşılamanın önemli bir etkisi olmalıdır.

\section{2. Misır Defineleri}

Aşağıdaki tabloda (Tablo 2) da gösterildiği üzere, Mısır'da MÖ 500'e tarihlenen Demanhur (IGCH 1637), MÖ 500-470 arası döneme tarihlenen Sakha (IGCH 1639) ile MÖ yaklaşık 475'e tarihlenen Asyut =IGCH $\mathbf{1 6 4 4}^{\mathbf{3 3}}$ definelerinde ağırlıklı olarak ThrakoMakedonya yerleşimleri ile Batı Anadolu ve Hellas'taki ticari faaliyetleriyle öne çıkan merkezlerin üretimi sikkeler temsil edilir. Özellikle, MÖ 6. ve 5. yüzyıldaki ticari faaliyetleriyle bilinen Khios, Samos, Klazomenai, Aigina gibi merkezlerin darphanelerinden çıkan sikkelerin bu definelerde temsil edilmesi dikkat çekicidir (Tablo 2).

\footnotetext{
${ }^{30}$ C. L. Nimchuk, "The 'Archers' of Darius: Coinage or Tokens of Royal Esteem?”, Ars Orientalis, Vol. 32, Medes and Persians: Reflections on Elusive Empires (2002), S. Freer Gallery of Art, The Smithsonian Institution and Department of the Historyof Art, University of Michigan, 2002, s. 57-58; Rider, 2001, s. 180.

${ }^{31}$ Hdt. III. 89, 90.

${ }^{32}$ Jack M. Balcer, "The Persian Occupation of Thrace 519-491 B.C. The Economic Effects", Actes du lle Congres international des Etudes du sud-est Européenes, Vol. 2, Athens 1972, s. 241-242; Pierre Briant, From Cyrus to Alexander: A History of the Persian Empire, Transl. by Peter T.Daniels, Eisenbrauns 2002, s. 741; J.M. Cook, "The Rise of Achaemenids and Establishment of Their Empire", The Cambridge History of Iran, Vol.2, Cambridge 1996, s. 219; R. N. Frye, The History of Ancient Iran, München, C.H. Beck'sche Verlagsbuchhandlung 1984, s. 103; Görkay, 1999, s. 198; Hdt. IV.1; FGrHist 688, F13, 16-22, Ktesias; Mehmet Ali Kaya, "Anadolu'da Pers Satraplıkları: Kuruluş, Yönetim ve Etnik Yapı”, CEDRUS: Akdeniz Uygarlıkları Araştırma Dergisi, Vol. VI, Akdeniz Üniversitesi Akdeniz Uygarlıkları Araştırma Enstitüsü Yayınları, 2018, s. 163; L. Llewellyn -J. ve J. Robson, Ctesias' History of Persia. Tales of the Orient, Routledge, London-New York 2010, s. 181; Polyain. Strat. VII. 11.

${ }^{33}$ Howgego, 2013, s. 122-124; M. Price et al., "Reviewed Work(s): Archaic Greek Coinage. The Asyut Hoard”, by Martin Price and NancyWaggoner, C. M. Kraay, The Journal of Helenic Studies, Vol. 97, 1977, s. 230-231; M. Price et al., "Reviewed Work(s): Archaic Greek Coinage. The Asyut Hoard", by Price Martin- NancyWaggoner, Reviewed by R. Ross Holloway, Gnomon, 50. Bd., H. 6, Oct., 1978, s. 597-600.
} 
Fariz ÖNCÜ

Tablo 2: MÖ 6. ve 5. Yüzyıllardaki Mısır Defineleri ve Define İçeriklerinin Bölgesel Dağılımı

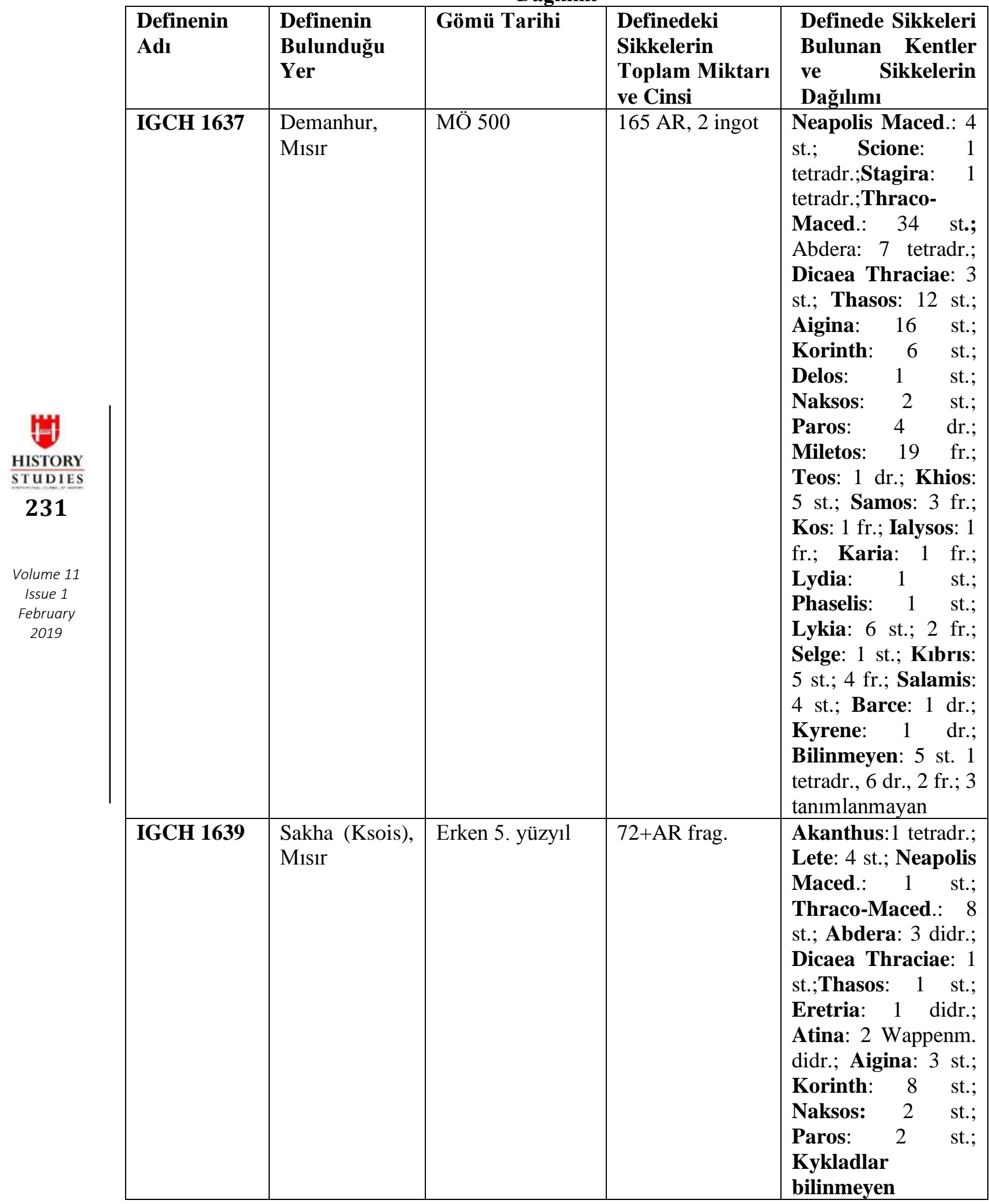




\begin{tabular}{|c|c|c|c|c|c|}
\hline & & & & 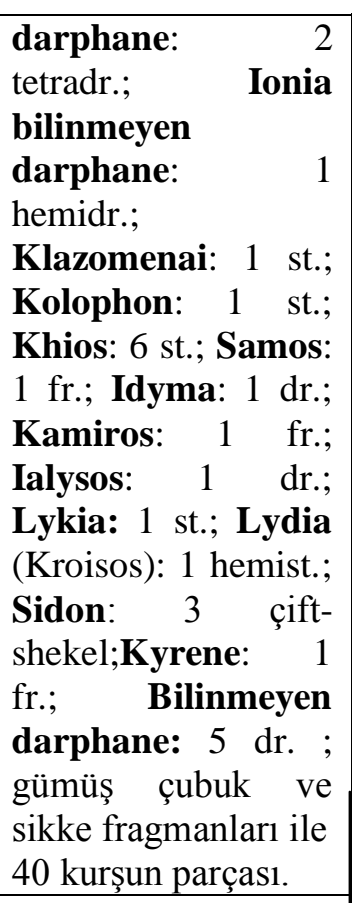 & HISTORY \\
\hline IGCH 1644 & $\begin{array}{l}\text { Asyut } \\
\text { (Lycopolis), } \\
\text { Misir. }\end{array}$ & MÖ Yak. 475 & $\begin{array}{ll}681+\mathrm{AR}, & +3 \\
\text { gümüş ignot }\end{array}$ & 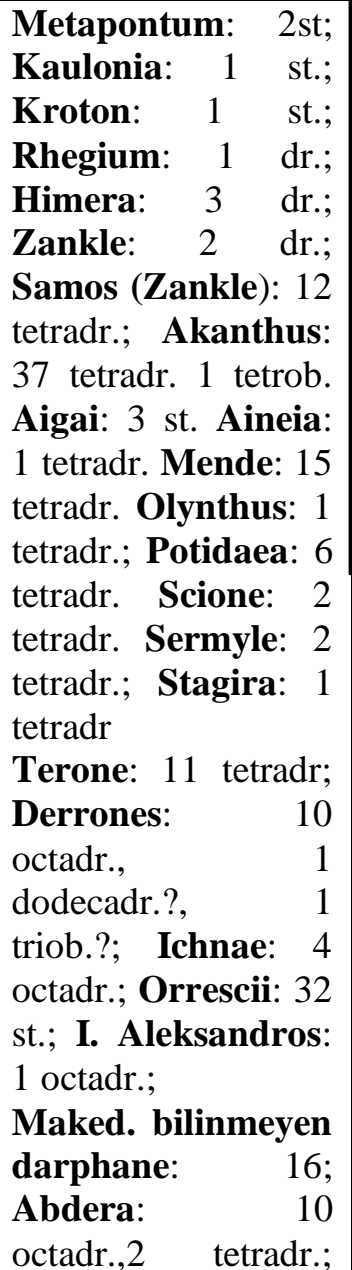 & $\begin{array}{l}\text { ST UDIES } \\
232 \\
\text { Volume 11 } \\
\text { Issue 1 } \\
\text { February } \\
2019\end{array}$ \\
\hline
\end{tabular}




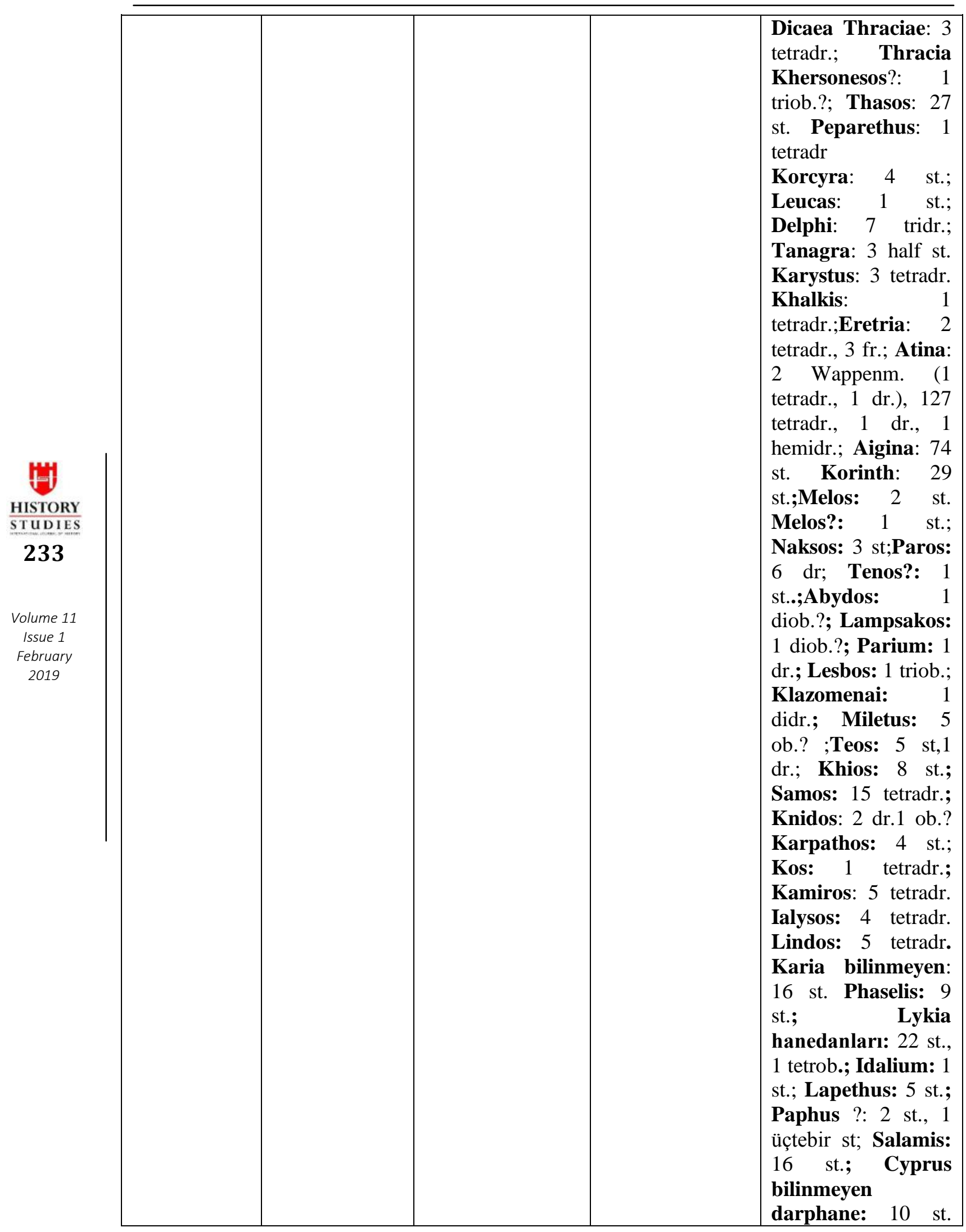




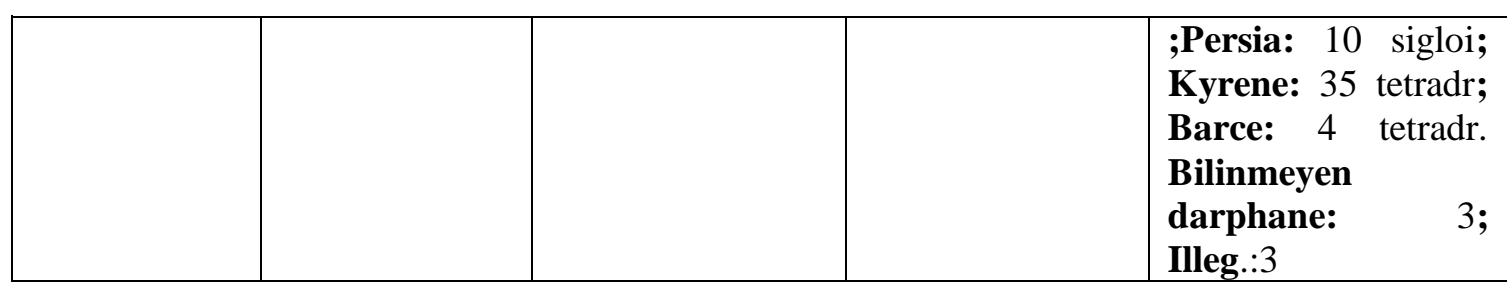

Bahsi geçen definelerdeki sikkelerin Mısır'a ulaşmasının en önemli sebeplerinden bir tanesi, Ras Samra Definesi’nde olduğu gibi, muhtemelen Pers krallarının gümüs kaynakları bakımından zayıf olan bölgeden vergileri gümüş olarak toplamak istemeleridir ${ }^{34}$. Ekonomik zenginliğini Nil Nehri’ne borçlu olan Mısır, tahıl üretimi açısından zengin bir bölgedir. Öyle ki, Pers egemenliği öncesinde Mısır'da tahıl değerli metal külçelerle birlikte para olarak yararlanılan temel araçlardan biridir. Ancak bu durum Mısır'ın, vergisini imparatorluğun merkezi hazinesine tahıl olarak ödediği anlamına gelmez. Başka bir ifadeyle, Pers yönetimi için verginin Mısır'dan tahıl yerine gümüş olarak toplanması daha avantajlı bir durum görümündedir. Çünkü coğrafi uzaklık nedeniyle, Persepolis ve Susa gibi imparatorluk merkezlerinin tahıl ihtiyacını Mısır'dan karşılamak, verginin değerini düşüren oldukça meşakkatli ve maliyetli bir yoldur.

Ayrıca, merkezi idarenin tahıl ihtiyacını Mısır yerine, bu ürünler açısından verimli ve imparatorluğun merkezine yakın olan Mezopotamya yerleşimlerinden karşılaması gibi daha uygun alternatifleri de vardır. Böyle bir tablo içinden bakıldığında, imparatorluk yönetimi için Mısır'dan vergiyi gümüş olarak toplamanın daha makul bir seçenek olduğu söylenebilir. Ancak Mısır gümüş kaynakları bakımından fakirdir. Bu yüzden, Perslerin gümüş olarak talep ettikleri vergi için kaynaklarını gümüşe dönüştürmeyi sağlayacak ticari faaliyetler içine girmesi gerekir. Bölgedeki definelerin sikke dağılımı, Mısır'ın gümüş kaynağına, ancak bu maden bakımından zengin; fakat tahıl ürünleri ve bazı ürünler (papirüs, natron ve keten gibi) açısından fakir olan, başta Atina ve Thrakia-Makedonya yerleşimleri olmak üzere, Hellen merkezleriyle yaptığı ticaretle ulaştığını gösterir. ${ }^{35}$ Dolayısıyla, burada sikkenin hem değerli bir ticari meta hem de Pers İmparatorluğu'na vergi olarak ödenecek bir gümüş kaynağı olarak bölgelerarası ticari faaliyetlerde işlem gördügü düşünülebilir. Bölgelerarası ticari etkinlikleriyle öne çıkan Khios, Samos, Klazomenai, Aigina gibi merkezlerin üretimi sikkelerin de bu definelerde temsil edilmesi, bu görüşü destekler niteliktedir.

\section{3. Taranto/Kalabria Definesi (IGCH 1874)}

MÖ yaklaşık 510 y1lına tarihlendirilen İtalya'daki Taranto/Kalabria Definesi (IGCH 1874) Thrakia ve Ege adalarındaki yerleşimlerden Hellas'a, Batı Anadolu'dan Güney İtalya'ya kadar birçok merkeze ait altı yüz gümüş sikke içerir (Tablo 3)

Tablo 3: Taranto/Kalabria Definesi ve Define İçeriğinin Bölgesel Dağılımı

\begin{tabular}{|l|l|l|l|l|}
\hline Definenin Adı & $\begin{array}{l}\text { Definenin } \\
\text { Bulunduğu } \\
\text { Yer }\end{array}$ & $\begin{array}{l}\text { Gömü } \\
\text { Tarihi }\end{array}$ & $\begin{array}{l}\text { Definedeki } \\
\text { Sikkelerin Toplam } \\
\text { Miktarı ve Cinsi }\end{array}$ & $\begin{array}{l}\text { Definede } \\
\text { Sikkeleri } \\
\text { Bulunan } \\
\text { Kentler } \\
\text { Sikkelerin }\end{array}$ \\
\hline
\end{tabular}

\footnotetext{
${ }^{34}$ Howgego, 2013, s. 122-123.

${ }^{35}$ Henry P. Colburn, The Archaeology of Achaemenid Rule in Egypt, (Yayımlanmamış Doktora Tezi), Michigan Üniversitesi, 2014, s. 352-353, 384-385; Figueira, 1998, s. 32.
} 
Fariz ÖNCÜ

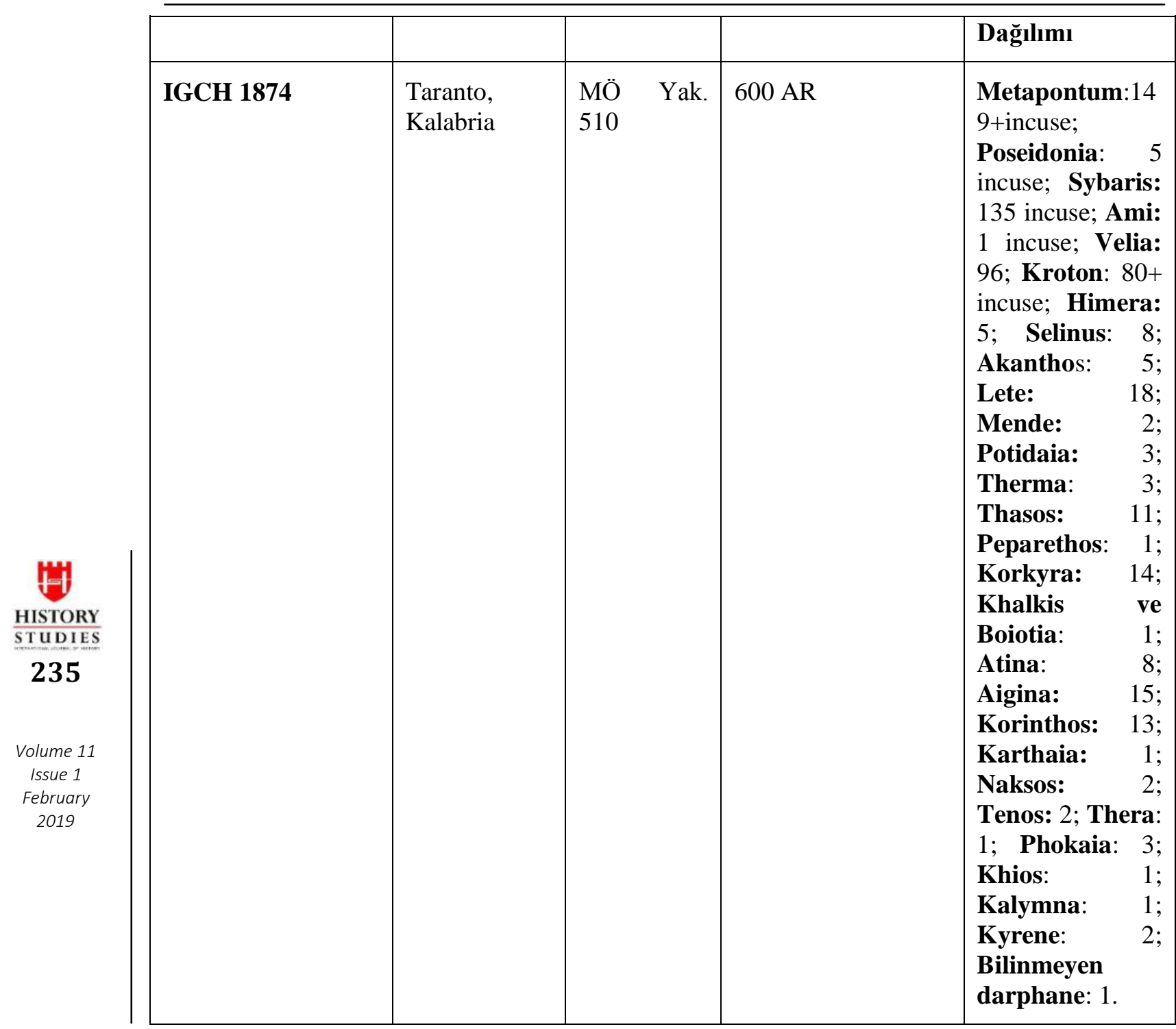

Kalabria Definesi'ndeki sikkelerin İtalya'nın bu bölgesine nasıl ve ne amaçla geldikleri hususunda herhangi bir yazılı kayit yoktur. Ancak Aigina, Atina, Korinthos, Thasos, Phokaia ve Khios gibi bölgelerarası ticari etkinlikleriyle öne çıkan merkezlere ait sikkelerin definede temsil edilmesi, söz konusu sikkelerin dolaşımında ticari faaliyetlerin rolünün güçlü bir ihtimal olarak ele almayı gerektirir. Perslerin egemenliğindeki Batı Anadolu yerleşimlerinden Khios ve Kalymna birer adet, Phokaia ise, üç adet sikkeyle definede temsil edilir. Bu durum, özellikle Batı Akdeniz'de kurduğu kolonilerle Pers öncesi dönemde Akdeniz'de önemli bir ticari üstünlüğe sahip olan Phokaia'nın ${ }^{36}$ bölgeyle ticari ilişkilerinin halen devam ettiği gösterir.

\footnotetext{
${ }^{36}$ Emre Okan, Phokaia Arkaik Dönem Ticari Amforalar, (Yayımlanmamış Doktora Tezi), Dokuz Eylül Üniversitesi, İzmir 2011, s. 151-154.
} 


\subsection{Yerel Sikkelerin Baskın Olduğu MÖ 5. Yüzyıl Defineleri}

MÖ 5. yüzyıla tarihli çok sayıda define vardır. Bunların önemli bir kısmı Anadolu'nun kıyı kesimleri ile kıyı şeridine yakın adalarda ele geçer. Aşağıdaki tabloda (Tablo 4) da görüldüğü üzere, bu definelerin çoğunda sayısal olarak yerel sikkeler baskın durumdadır. Hatta bazı defineler sadece yerel sikkelerden oluşur; gömü yeri Khios olan ve MÖ yaklaşık 460'a tarihlenen definede (IGCH 1179) yirmi altıdan fazla sadece Khios stateri ${ }^{37}$ ele geçer. Gömü yeri Karia/Lykia sınırı olan ve MÖ yaklaşık 460'a tarihlenen definede (IGCH 1181) Karia'nın lokasyonu tespit edilemeyen bir bölgesine ait yediden fazla statere rastlanır. Gömü yeri Halikarnassos (Bodrum) olan ve MÖ yaklaşık 450'ye tarihlenen definede (IGCH 1186) iki bin civarında sadece Knidos (Datça) gümüş sikkesi bulunur ${ }^{38}$. Gömü yeri Lesbos olan ve MÖ yaklaşık 450'e tarihlenen definede (IGCH 1187) elli altıdan fazla sadece Mthymna gümüş sikkesi ele geçer. Gömü yeri Kuzey Anadolu olarak geçen ve MÖ yaklaşık 450'e tarihlenen definede (IGCH 1235) Sinope'ye ait yirmi birden fazla gümüş drahmi bulunur ${ }^{39}$. Gömü yeri Kuzey Anadolu olarak geçen ve MÖ yaklaşık 5. yüzyıla tarihlenen definede (IGCH 1236) Sinope'ye ait beş yüz civarında gümüş drahmi ele geçer. Gömü yeri Khios'taki Phanai olan ve MÖ yaklaşık 450-440'a tarihlenen definede (IGCH 1191) on beşi didrahmi ve kırk dördü tatraobolos olmak üzere toplam elli dokuz Khios gümüş sikkesine rastlanır. Gömü yeri Lesbos'taki Mytilene olan ve MÖ yaklaşık 450-400 dönemine tarihlenen definede (IGCH 1192) yediden fazla sadece Lesbos stateri ${ }^{40}$ ele geçer.

Gömü yeri Lykia olan ve MÖ yaklaşık 450’ye tarihlenen definede (IGCH 1250) Lykia bölgesine ait altmış üçten fazla lejantsız gümüş stater bulunur. Gömü yeri Kaş (Antiphellos) olan ve MÖ yaklaşı $440-430$ 'a tarihlenen definede (IGCH 1251) birkaç Atina tetradrahmisi (17. 2 gram) dışında, neredeyse bütün gümüş staterler (yüzden fazla) Lykia hanedanlarının üretimidir ${ }^{41}$. Gömü yeri Kıbrıs olarak geçen ve MÖ yaklaşı 425-400'e tarihlenen definede (IGCH 1277) Thasos'a ve Lykia'ya (hanedan Kheriga'ya ) ait birer sikke fragmanı dışında, neredeyse bütün gümüş staterler (en az dokuz tanesi) Kıbrıs’taki darphanelerin (Idalium, Lapethos, Paphos, Salamis) üretimidir. Gömü yeri Güney Anadolu olan ve MÖ yaklaşık 420'ye tarihlenen definede (IGCH 1253) sadece Aspendos'a ait otuz beşten fazla gümüş stater ele geçer. Gömü yeri Karia (?) olan ve MÖ yaklaşık 410'a tarihlenen definede (IGCH 1193) yüz civarında sadece Knidos drahmisine rastlanır. Gömü yeri Batı Anadolu olan ve MÖ yaklaşık 5. yüzyıla tarihlenen definede (IGCH 1196) on dörtten fazla sadece Miletos obolosü

\footnotetext{
${ }^{37} 15.6$ gramlık tetradrahmilerin darp edildiği Khios ağıllı sisteminde, drahmi ve daha alt birimlerdeki sikkeler de üretilmiştir. Khios'ta, ayrıca, Miletos ağırlık sistemine (14. 1 gramlık stater) uygun darp edilmiş sikkelere de rastlanır. Bkz. Tekin, 2008, s. 36.

${ }^{38} \mathrm{MÖ}$ 6. yüzyılın üçüncü çeyreğinden sonra Miletos ağırlık sisteminde küçük birimlerde gümüş sikke darp etmeye başlayan Knidos, daha sonra muhtemelen ticari kaygılardan dolayı sikke üretiminde Aigina ağırlık sistemini (12.2 gramlık stater) kullanır. Bkz. Kraay, 1976, s. 38; Görkay, 1999, s. 197; Pernille Flensted- Jensen, "Karia”, An Inventory of Archaic and Classical Poleis, M. H. Hansen -T. H. Nielsen (eds), Oxford University Press, New York, 2004, s. 1125; Tekin, 2008, s. 35. MÖ 5. yüzyılın sonlarında ise, Knidos, Rhodos ağırlık sisteminde ( 15.6 gramlık tetradrahmi) sikke üretimine başlar. Bkz. Kraay, 1976, s. 246; Stephen Mitchell, "Troas" An Inventory of Archaic and Classical Poleis, M. H. Hansen -T. H. Nielsen (eds), Oxford University Press, New York, 2004, s. 1003.

${ }^{39}$ Sinope, MÖ 5. yüzyılda Aigina ağırlık sisteminde sikke darp eden merkezler arasında yer alır. Bkz. Kraay, 1976, s. 245. Değişik tip ve birimlerde darp edilmiş Sinope üretimi sikke örnekleri için bkz. Öncü, 2018, Levha V, No. 99-102.

${ }^{40}$ Lesbos, Phokaia ağırlık sisteminin (16.1 gramlık stater) sikke üretiminde kullanıldığı bölgeler arasında yer alır.

${ }^{41}$ Lykia'nın batı kesimlerinde genellikle 8.3-8.6 gram ağırlı̆̆ında sikkeler darp edilirken, bölgenin orta kesimlerinde 9.5-10 gram sikkeler darp edilir. Bkz. Tekin, 2008, s. 36. Lykia bölgesindeki çeşitli hanedanlara atfedilen ve değişik birimlerde darp edilmiş sikke örnekleri için ayrıca bkz. Öncü, 2018, Levha VIII, No. 158-191.
} 
ele geçer. Gömü yeri Samos olan ve MÖ yaklaşık 400'e tarihlenen definede (IGCH 1198) 10 civarında sadece Samos tetradrahmisi (13. 1 gram) bulunur. ${ }^{42}$

Tablo 4: Yerel Sikkelerin Baskın Olduğu Defineler ve İçerikleri

\begin{tabular}{|c|c|c|c|c|c|}
\hline \multirow{9}{*}{$\begin{array}{c}\begin{array}{c}\text { HU } \\
\text { HISTORY }\end{array} \\
\frac{\text { STUDIES }}{237} \\
\\
\text { Volume 11 } \\
\text { Issue 1 } \\
\text { February } \\
2019\end{array}$} & Definenin Adı & $\begin{array}{l}\text { Definenin } \\
\text { Bulunduğu Yer }\end{array}$ & $\begin{array}{l}\text { Gömü } \\
\text { Tarihi }\end{array}$ & $\begin{array}{l}\text { Definedeki } \\
\text { Sikkelerin } \\
\text { Toplam Miktarı } \\
\text { ve Cinsi }\end{array}$ & $\begin{array}{l}\text { Definede } \\
\text { Sikkeleri } \\
\text { Bulunan } \\
\text { Kentler } \\
\text { Sikkelerin } \\
\text { Dağılımı }\end{array}$ \\
\hline & IGCH 1166 & $\begin{array}{l}\text { Bayrakl1, İzmir } \\
\text { (Smyrna), Ionia }\end{array}$ & $\begin{array}{l}\text { MÖ Yak. } \\
500-490 .\end{array}$ & $20 \mathrm{AR}$ & $\begin{array}{lr}\text { (Smyrna?): } 14 \\
\text { ob.; Lydia: } 2 \\
\text { sigloi ; Persia: } 4 \text { : } \\
\text { sigloi }\end{array}$ \\
\hline & IGCH 1178 & $\begin{array}{l}\text { Çal Dağı, Sardeis } \\
\text { Yakınında, Lydia }\end{array}$ & MÖ Yak. 470 & Yak. 2000 AR & $\begin{array}{l}\text { Lydia:475+hemi } \\
\text { st. (Kroisos } \\
\text { Tipi); Persia: } \\
98+\text { sigloi (Yarım } \\
\text { kral tasviri); } \\
537+\text { sigloi( ok } \\
\text { atıcı kral); } 310+ \\
\text { sigloi (mızrak } \\
\text { taşıyan kral). }\end{array}$ \\
\hline & IGCH 1179 & Khios, Ionia & MÖ Yak. 460 & $26+\mathrm{AR}$ & Khios: st. \\
\hline & IGCH 1181 & Karia, Lykia Sınırı & MÖ Yak. 460 & $7+\mathrm{AR}$ & $\begin{array}{l}\text { Karia, } \\
\text { Bilinmeyen } \\
\text { basım: } 7+\text { st. }\end{array}$ \\
\hline & IGCH 1186 & $\begin{array}{l}\text { Bodrum } \\
\text { (Halikarnassos), } \\
\text { Karia }\end{array}$ & MÖ Yak. 450 & Yak. 2000 AR & Knidos: dr. \\
\hline & IGCH 1187 & Lesbos & MÖ Yak. 450 & $56+\mathrm{AR}$ & $\begin{array}{l}\text { Mthymna: } \\
\text { 4+didr.; } 44+ \\
\text { terob., } 8+\text { diob. }\end{array}$ \\
\hline & IGCH 1191 & $\begin{array}{l}\text { Khios'taki Phanai, } \\
\text { Ionia }\end{array}$ & $\begin{array}{l}\text { MÖ Yak. } \\
450-440\end{array}$ & $59 \mathrm{AR}$. & $\begin{array}{l}\text { Khios: } 15 \text { didr. ; } \\
44 \text { tetrob. }\end{array}$ \\
\hline & IGCH 1192 & Mytilene, Lesbos & $\begin{array}{l}\text { MÖ } \\
450-400\end{array}$ & 7+BIL & Lesbos: st. \\
\hline
\end{tabular}

${ }^{42}$ Bkz. Tablo 4; Figueira, 1998, s. 41; Tekin, 2008, s. 37. 
Persler /Akhaemenidler Dönemindeki Bölgelerarası Ticari Ilişkiler Bağlamında Mö 6. ve 5. Yüzyıl Sikke Defineleri

\begin{tabular}{|c|c|c|c|c|}
\hline IGCH 1193 & Karia? & MÖ Yak. 410 & Yak. 100 AR & Knidos: dr. \\
\hline IGCH 1195 & Ionia & $\begin{array}{l}\text { M.Ö. } \\
\text { yüzy1l }\end{array}$ & $22 \mathrm{AR}$ & $\begin{array}{l}\text { Miletos: } 21 \text { ob.; } \\
\text { Ialysus: } 1 \text { ob. }\end{array}$ \\
\hline IGCH 1196 & Batı Anadolu & MÖ 5. Yüzyıl & $14+\mathrm{AR}$ & Miletos: ob. \\
\hline IGCH 1197 & $\begin{array}{l}\text { Izmir (Smyrna) } \\
\text { bölgesi, Ionia }\end{array}$ & MÖ Yak. 400 & $271 \mathrm{AR}$ & $\begin{array}{lr}\text { Persia: } & \text { sigloi } \\
\text { (mizrak } & \text { taşıyan } \\
\text { kral) } & \end{array}$ \\
\hline IGCH 1198 & Samos, Ionia & MÖ Yak. 400 & Yak. 10 AR & Samos: tetradr. \\
\hline IGCH 1235 & Kuzey Anadolu & MÖ Yak. 450 & $21+\mathrm{AR}$ & Sinope: $\mathrm{dr}$. \\
\hline IGCH 1236 & Kuzey Anadolu & MÖ 5. Yüzyıl & Yak. 500 AR & Sinope: $\mathrm{dr}$. \\
\hline IGCH 1250 & Lykia & MÖ Yak. 450 & $63+\mathrm{AR}$ & Lykia: yazısız st. \\
\hline IGCH 1251 & $\begin{array}{l}\text { Lykia, Kaş(ant. } \\
\text { Antiphellos) }\end{array}$ & MÖ 440-430 & $100+A R$ & $\begin{array}{l}\text { Atina: } \\
\text { 3+tetradr.; Lycia } \\
\text { hanedanları: } \\
\text { 96+st. }\end{array}$ \\
\hline IGCH 1253 & Güney Anadolu & MÖ Yak. 420 & $35+\mathrm{AR}$ & Aspendos: st. \\
\hline IGCH 1277 & Kibris & $\begin{array}{l}\text { MÖ } \\
425-400\end{array}$ & $11+\mathrm{AR}$ & $\begin{array}{l}\text { Thasos: } 1 \text { fr.; } \\
\text { Lykia, Kheriga: } \\
1 \text { fr.; Idalium: } 2 \\
\text { fr.; Lapethos: } 1 \\
\text { st.; Paphos: } 3 \\
\text { st.; Salamis: } 2 \text { st: } \\
\text { Bilinmeyen } \\
\text { Kubris } \\
\text { darphanesi: } 1 \text { st. }\end{array}$ \\
\hline
\end{tabular}

Yerel üretimlerin definelerdeki baskın karakteri MÖ 5. yüzyıl boyunca Sardeis Satraplığı'nın Batı Anadolu'daki toprakları olarak düşünülen bölgelerde ortaya çıkan diğer definelerin içeriğinde de kendini gösterir. MÖ yaklaşık 500-490 y1llarına tarihli ve Smyrna'da (İzmir/Bayraklı) bulunan bir definede (IGCH 1166) on dördü Smyrna (?) obolosü ve altıs1 Pers siglosu olmak üzere toplamda yirmi gümüşs sikke ele geçer (Tablo 4).

Bunun yanı sıra, MÖ yaklaşık 470'e tarihlenen ve Sardeis yakınında bulunan Çal Dağı Definesi'nde (IGCH 1178) iki bin civarında gümüss sikkeye rastlanır. Bu sikkelerin en az dört yüz yetmiş beşi kroesoid hemistaterden ve en az dokuz yüz kırk beşi Pers sigloidan oluşur (Tablo 4). 
Kazı çalışmalarından elde edilen veriler de Siglosların kullanımının Sardeis ve yakın çevrelerinde yoğunluk kazandığını gösterir. Bu çalışmalar sonucunda Sardeis’te altı sigloi ele geçer. Diğer bölgelerde ise herhangi bir siglos ya da dareikos buluntusuna rastlanmaz. ${ }^{43}$

Yine MÖ yaklaş1k 400'e tarihli ve Smyrna'da (İzmir çevresi) bulunan bir definede (IGCH 1197) tamamı mızrak taşıyan kral figürünün üzerinde yer aldığı toplam iki yüz yetmiş bir Pers sigloi bulunur. ${ }^{44}$ Küçük Asya olarak kayda geçen ve MÖ 450-425'e tarihlenen bir diğer definede ise, bulunan sigloi sayısı üç yüz elliden fazladır. ${ }^{45}$

Değişik bölgelerin üretimlerini bir arada temsil eden bazı definelerde bile (örneğin IGCH 1195) yerel sikkelerin baskın durumları kendini gösterir (Tablo 4). Dolayısıyla, yukarıda bahsi geçen söz konusu definelerin bölgesel dağılımları göz önüne alındığında, sikke üretiminin önemli bir kısmının yerel ihtiyaçları karşılamak için darp edildiği ve coğrafi olarak sınırlı kullanım alanlarına sahip olduğu söylenebilir.

\subsection{Elektron Sikkeler İçeren Defineler}

Anadolu'nun kıyı şeridinde ve yakın adalarda farklı darphanelere ait sikkeleri barındıran ve MÖ 5. yüzyılın değişik dönemlerine tarihlendirilen bazı defineler, Tablo 5'te görüldügü üzere, bulundurdukları elektron sikkelerle dikkat çeker.

Tablo 5: Elektron Sikkeler İçeren Defineler ve Bu Sikkelerin Bölgesel Dağılımları

\begin{tabular}{|c|c|c|c|c|}
\hline $\begin{array}{l}\text { Definenin } \\
\text { Adı }\end{array}$ & $\begin{array}{l}\text { Definenin Bulunduğu } \\
\text { Yer }\end{array}$ & $\begin{array}{l}\text { Gömü } \\
\text { Tarihi }\end{array}$ & $\begin{array}{l}\text { Definedeki } \\
\text { Sikkelerin } \\
\text { Toplam } \\
\text { Miktarı ve } \\
\text { Cinsi }\end{array}$ & $\begin{array}{l}\text { Definede Sikkeleri Bulunan } \\
\text { Kentler ve Sikkelerin } \\
\text { Dağılımı }\end{array}$ \\
\hline $\begin{array}{l}\text { IGCH } \\
1002\end{array}$ & $\begin{array}{l}\text { Olbia (Parutino), } \\
\text { Ukrayna }\end{array}$ & $\begin{array}{l}\text { MÖ 450- } \\
400\end{array}$ & $8+\mathrm{EL}$ & Kyzikos: st. \\
\hline $\begin{array}{l}\text { IGCH } \\
1184\end{array}$ & Erythrai, Ionia & $\begin{array}{l}\text { MÖ Yak. } \\
455\end{array}$ & $\begin{array}{l}79+\mathrm{EL}, 16+ \\
\mathrm{AR}\end{array}$ & $\begin{array}{l}\text { Lesbos: } 57 \text { EL 1/6; } \\
\text { Klazomenai: } 3 \text { didr.; } \\
\text { Phocaia: } 11 \text { EL 1/6; Khios: } \\
10 \text { dr.; Bilinmeyen } \\
\text { Darphane: } 11 \text { EL yarım. }\end{array}$ \\
\hline $\begin{array}{l}\text { IGCH } \\
1194\end{array}$ & $\begin{array}{l}\text { Vourla(Klazomenai), } \\
\text { Ionia }\end{array}$ & $\begin{array}{l}\text { MÖ Yak. } \\
410-400 .\end{array}$ & $90 \mathrm{EL}, \mathrm{Av}$ & $\begin{array}{l}\text { Kyzikos, } 70 \text { EL st. ; } \\
\text { Lampsacos: } 20 \text { EL st. } \\
\text { Persia: birkaç dareikos }\end{array}$ \\
\hline $\begin{array}{l}\text { IGCH } \\
1234\end{array}$ & $\begin{array}{l}\text { Işıklıköy, Mudanya } \\
\text { yakınlarında } \\
\text { (Apameia-Mrlea), } \\
\text { Bithynia. }\end{array}$ & $\begin{array}{l}\text { MÖ Yak. } \\
460\end{array}$ & $29 \mathrm{EL}, 312 \mathrm{AR}$ & $\begin{array}{l}\text { Kyzikos: } 9 \text { EL } 1 / 6,19 \text { EL } \\
\text { 1/12, } 284 \text { AR fr.; } \\
\text { Lampsakos: } 24 \text { AR fr. } \\
\text { Phokaia: } 1 \text { EL } 1 / 6 \text {; } \\
\text { Bilinmeyen darphane: } 4 \\
\text { AR fr. }\end{array}$ \\
\hline
\end{tabular}

\footnotetext{
${ }^{43}$ Zeynep. Ç. Öğün ve M.-C. Marcellesi, "Réseaux d'échanges régionaux en Asie Mineure occidentale: l'apport des monnaies de fouilles", avec Z. Çizmeli-Öğün, dans Th. Faucher, M.-C. Marcellesi, O. Picard (ed.), Nomisma. La circulation monétaire dans le monde grec antique, BCH suppl. 53, Athènes 2011, s. 312, fig. 6.

${ }^{44}$ Bkz.Tablo 4; Figueira, 1998, s. 41-42.

${ }^{45}$ Figueira, a.g.e., 42.
} 
Gömü yeri Apameia-Myrlea (Mudanya/Işıklıköy) olan ve MÖ yaklaşık 460’a tarihlendirilen define (IGCH 1234) kayda değer oranda elektron sikke içerir (Tablo 5). Gömü yeri Erythrai olan ve MÖ yaklaşı 455'e tarihlenen IGCH 1184 Definesi ile gömü yeri Klazomenai olan ve MÖ yaklaşı 410-400 dönemleri arasına tarihlendirilen IGCH 1194 Definesi yüksek oranlarda elektron sikke barındıran diğer önemli definelerdir (Tablo5). Apameia-Myrlea Definesi (IGCH 1234), staterin 1/6 biriminde dokuz, 1/12 biriminde on dokuz adet Kyzikos elektron sikkesi ${ }^{46}$ ve $1 / 6$ biriminde bir adet Phokaia elektron stater ${ }^{47}$ barındırır. Definede ayrıca iki yüz seksen dört Kyzikos üretimi, yirmi dört Lampsakos üretimi ve dört adet de bilinmeyen bir darphaneye ait olmak üzere toplam üç yüz on iki gümüş sikke fragmanı da ele geçer. Erythrai Definesi'nde (IGCH 1184) yetmiş dokuzdan fazla elektron sikke bulunur. Bu definede, staterin altıda biri (hektae) olan elli yedi elektron sikke Lesbos'a, on biri Phokaia'a atfedilirken, yarım stater on bir elektron sikkenin ise üretim yeri belli değildir. Geriye kalan sikkelerden didrahmi birimindeki üçer tanesi Klazomenai ve Erythraia'a, drahmi biriminde on sikke ise Khios'a atfedilir. Vourla Definesi'nde (IGCH 1194) ise, yetmişi Kyzikos'a ve yirmisi Lampsakos'a ait toplam doksan elektron sikkeye ulaşılır. Bu definede, birkaç tane de Pers kralının altın parası dareikos ele geçer (Tablo5).

Elekron sikkeler, yüksek değerlerinden dolayı günlük alış verişler için kullanılacak uygun paralar değildir. ${ }^{48} \mathrm{Bu}$ sikkelerin daha çok uzun mesafeli ticarette kullanıldıkları bilinir. ${ }^{49}$ Özellikle Marmara Denizi'nin güneyinde yer aldığı konumuyla Kyzikos yerleşimi, Karadeniz, Marmara, Ionia ve Atina arasında gerçekleşen bölgelerarası ticaret için uygun bir aracı merkez rolündedir. ${ }^{50}$ Kyzikos elektron staterlerinin başta Karadeniz kıyı kesimleri olmak üzere birçok bölgede dolaşımda olması, daha çok onun bölgelerarası ticari işlemlerde kullanımıyla ilgili olmalıdır. MÖ yaklaşık 460'a tarihlenen ve Phokaia ile Kyzikos elektron sikkeleri içeren Apemea-Myrlea Definesi (IGCH 1234), elektronun Marmara (Propontis) ve Karadeniz (Pontus) ticaretindeki önemini düşündüren MÖ 5. yüzyılın erken dönem örnekleri arasında yer alır. Lampsakos ve Kyzikos gümüş sikke fragmanlarının da aynı zamanda definede yer alması, bölgelerin yakınlığı göz önüne alındığında, ticari ilişkiler bakımından beklenebilir bir durumdur. ${ }^{51}$

MÖ 450-400 arası döneme tarihlendirilen Ukrayna'daki bir define (Olbia Definesi: IGCH 1002) sekizden fazla Kyzikos elektron staterinden oluşur (Tablo 5). Olbia'nın Hellen polislerinin tahıl ihtiyacının karşılanmasında önemli bir merkez olduğu göz önünde tutulduğunda $^{52}$, bu Kyzikos elektron staterlerinin ticari amaçla dolaşıma girdikleri kuvvetle muhtemeldir. Perikles'in MÖ yaklaşık 437/36'da gerçekleştirdiği Karadeniz seferi ${ }^{53}$, Thrakia'nın kıyı kesimlerinde deniz ticaretinin daha da canlanmasını sağlar. Ticaretteki bu canlılıkta tahı ithalatının önemli bir rolü vardır. ${ }^{54}$ Kyzikos staterlerinin (kyzikene) bölgelerarası bu ticarette uluslararası bir değişim aracı olarak daha da önem kazandığ 1

\footnotetext{
${ }^{46}$ Kyzikos, elektron sikke darbında Phokaia ağırlık sisteminin (16.1 gramlık elektron stater) kullanıldığı yerleşim birimlerinden biridir. Bkz. Tekin, 2008, s. 37. Değişik birim ve tiplerde darp edilmiş Kyzikos sikke örnekleri için bkz.Öncü, 2018, Levha V, No. 103-112.

${ }^{47}$ Sikke üretiminde Aigina, Atina (Bodenstedt, 1976, s. 56, 90-91; Görkay, 1999, s. 196) ve kendi ağırlık sistemini (16.1 gramlık stater ve alt birimleri) kullanan (Tekin, 2008, s. 37) Phokaia'nın farklı tip ve birimlerde ürettiği sikke örnekleri için bkz. Öncü, 2018, Levha IV, No. 73-79.

${ }^{48}$ Howgego, 2013, s. 23.

${ }^{49}$ Bodenstedt, 1976, s. 74; Figueira, 1998, s. 42-43.

${ }^{50}$ Kraay, 1976, s. 261.

${ }^{51}$ Figueira, a.g.e., s. 30.

${ }^{52}$ Psoma, 2016, s. 97.

${ }^{53}$ Plut. Per. 20

${ }^{54}$ Figueira, 1998, s. 29-30, 515.
} 
düşünülebilir. Yine Phokai'nın elektron sikkelerinin üretim amaçlarından birinin uzun mesafeli ticaret olduğu öne sürülen iddialar arasındadır. ${ }^{55}$ Elektron sikkelerin, özellikle de Kyzikos staterlerinin, bölgelerarası ticaretteki rolü dikkate alındığında, definelerde adı geçen merkezler arasında MÖ 5. yüzyıl boyunca ticari ilişkilerin devam ettiğini kabul etmek gerekir.

Ancak, özellikle Vourla Definesi'nde (IGCH 1194), Kyzikos elektron staterlerinin Pers dareikosleriyle birlikte yer alması, bu sikke dolaşımının başka nedenleri de olabileceğini düşündürür. Batı Anadolu'da yaklaşık M.Ö. 480'e tarihlendirilen başka bir definede (IGCH 1175) staterin üçte biri ağırlığında olan iki Lydia elektron sikkesi, altı gümüş kroesoid, otuz dokuz Pers sigloi, üç Miletos üretimi ve on dört Kyzikos üretimi gümüş sikke fragmanı ele geçer. MÖ 480 ve civarı dönemler Kserkses'in Hellas üzerine sefer düzenlemek için hazırlandığı ve nihayetinde sefere çıktığı bir döneme denk gelir. ${ }^{56}$ Dolayısıyla, Kyzikos ve Pers sikkelerinin bir arada bulunduğu bir dönemin askeri bir sefere denk gelmesi, bu sikkelerin dolaşımında askeri faaliyetlerin rolünün hesaba katmayı gerektirir. Dareikos ve Kyzikos elektron staterlerinin yakın değerde oldukları ve bazı dönemlerde, tesadüfi ya da değil, benzer amaçlarla kullanıldıkları bilinir. Buradaki temel belirleyici nokta, bir dareikos ${ }^{57}$ ile bir Kyzikos staterinin paralı bir askerin bir aylık maaşına denk gelmesidir. ${ }^{58}$ Böyle yüksek bir oranı ancak Persler tarafından kiralanan askerlerin alabilme ihtimali vardır. ${ }^{59}$ MÖ 5. yüzyılın sonlarında Genç Kyros'un, içinde Hellen paralı askerlerinin de yer aldığı bir taht kavgasına giriştiği bilinir. ${ }^{60}$ Yine MÖ 410'ların sonları Batı Anadolu'da Atina'ya karşı, Sparta ve Persler lehine isyanların yoğun olarak yaşandığı bir dönemdir. Bu yüzden, Vourla Definesi’nin (IGCH 1194) gömü tarihi (MÖ yak. 410-400) dikkate alındığında, bu sikkelerin dolaşımında paralı askerlerin rolü ihtimaller arasında sayılabilir.

\subsection{Diğer Defineler}

Yukarıda bahsi geçen defineler dışında, Tablo 6'da da gösterildiği üzere, Rhodos, Troia,

Kolophon, Güney Anadolu ve Hellas bölgelerinin birçok yerinde ele geçen ve değişik bölgelerin üretimi sikkeleri bir arada bulunduran birçok sikke definesi daha bilinir.

Tablo 6: IGCH 6, IGCH 7, IGCH 21, IGCH 1177, IGCH 1183, IGCH 1185, IGCH 1188, IGCH 1189, 1190, IGCH 1254, IGCH 1255 Numaralı Sikke Definelerinin İçerik ve Bölgesel Dağılımı

\begin{tabular}{|l|l|l|l|l|}
\hline $\begin{array}{l}\text { Definenin } \\
\text { Adı }\end{array}$ & $\begin{array}{l}\text { Definenin } \\
\text { Bulunduğu } \\
\text { Yer }\end{array}$ & Gömü Tarihi & $\begin{array}{l}\text { Definedeki } \\
\text { Sikkelerin } \\
\text { Toplam Miktarı } \\
\text { ve Cinsi }\end{array}$ & $\begin{array}{l}\text { Definede Sikkeleri } \\
\text { Bulunan Kentler ver } \\
\text { Sikkelerin Dağılımı }\end{array}$ \\
\hline IGCH 6 & Kyklades? & MÖ Yak. 500 & $145+$ AR & $\begin{array}{l}\text { Aigina: } 114+\text { st.; Andros } \\
\text { ya da Keos: 4 st.; Paros: 2 } \\
\text { st.; Siphnos: 4 st.; Thera?: } \\
\text { 11 st.; Dardanos: 1 st.; } \\
\text { Miletos?: 2 st.; Khios: } 3 \\
\text { st.; Kos: 4 st. }\end{array}$ \\
\hline
\end{tabular}

\footnotetext{
${ }^{55}$ Bodenstedt, 1976, s. 74.

${ }^{56}$ Hdt. VI. 1, 4; VII. 223-238; VIII. 1-86.

${ }^{57}$ Xen. Anab. VII.6.1; VII.6.7.

${ }^{58}$ Figueira, a.g.e., 525-527; Kraay, 1976, s. 263.

${ }^{59}$ H. P. Borrell, "United Autonomous and Imperial Greek Coins" The Numismatic Chronicle and Journal of the Numismatic Society, Vol. 6, Ed. J. Y. Akerman, London, 1843/1844, s. 153.

${ }^{60}$ Xen. Anab. I.1.1-6.
} 


\begin{tabular}{|c|c|c|c|c|}
\hline IGCH 7 & $\begin{array}{l}\text { Santorin } \\
\text { Thera) }\end{array}$ & $\begin{array}{l}\text { MÖ Yak. 500- } \\
490\end{array}$ & $760+\mathrm{AR}$ & 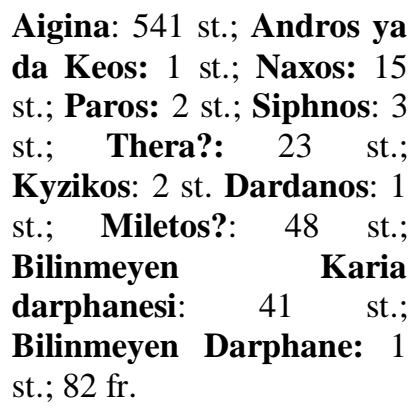 \\
\hline IGCH 21 & $\begin{array}{l}\text { Koumares, } \\
\text { Thessalia }\end{array}$ & MÖ Yak. 450 & Yak. 36 AR & $\begin{array}{l}\text { Aigina: } 35 \text { st.; Khios: } 1 \\
\text { arkaik st. }\end{array}$ \\
\hline IGCH 1177 & $\begin{array}{l}\text { Güney } \quad \text { Batı } \\
\text { Anadolu, } \\
\text { Kilikia- } \\
\text { Pamphylia } \\
\text { Sinırı }\end{array}$ & MÖ Yak. 480 & $38 \mathrm{AR}$ & $\begin{array}{l}\text { Zancle: } 1 \text { tetradr.; } \\
\text { Acanthos: } 1 \text { tetradr.; } \\
\text { Abdera: 1 octadr.; Atina: } \\
\text { 19 tetradr.; Aegina: } 10 \\
\text { didr.; Pseudaeginetica: } 1 \\
\text { didr. Parium: 1 dr. ; } \\
\text { Khios: 1 didr. Beli } \\
\text { olmayan Karia: 1 double } \\
\text { siglos; Persia: } 1 \text { siglos. }\end{array}$ \\
\hline IGCH 1183 & Kolophon, Ionia & MÖ Yak. 450? & $\begin{array}{l}3 \text { EL fr. , } 177 \text { AR } \\
\text { fr. , I PL }\end{array}$ & $\begin{array}{l}\text { Kyzikos: 1; Lampsacos: 2; } \\
\text { Kyme: 1; Klazomenai?: } \\
\text { 13; Kolophon: 74; } \\
\text { Ephesos: 10; Erytrai ?: 1; } \\
\text { Magnesia?: 26; Miletos: 2; } \\
\text { Phocaia: 1 ; Teos: 38; } \\
\text { Samos: 1; Karia: 1; Pers } \\
\text { Kralları: 2; Bilinmeyen } \\
\text { darphaneler: 3 EL, } 4 \text { AR, } \\
\text { 1 PL }\end{array}$ \\
\hline IGCH 1185 & Rhodos & MÖ Yak. 450 & $41+\mathrm{AR}$ & $\begin{array}{l}\text { Dicaia: } 1 \text { didr.; Thasos: } 8 \\
\text { didr. Lete: } 3 \text { didr. Mende: } \\
1 \text { tetradr.; Neapolis: } 1 \text { didr.; } \\
\text { Stagira: } 1 \text { teradr., } 2 \text { didr.; } \\
\text { Bilinmeyen Throco- } \\
\text { Maked.: } 3 \text { didr.; Aigina: } 2 \\
\text { didr.; Tenos: } 1 \text { didr. ; } \\
\text { Thera ?: } 1 \text { didr. Phocaia: } 1 \\
\text { teradr.; Lykia: } 3 \text { st.; } \\
\text { Phaselis: } 1 \text { double siglos; } \\
\text { Soli: 1 double siglos; } \\
\text { Kyrene: } 3 \text { teradr., } 3 \text { dr.; } \\
\text { Barce : } 1 \text { dr. Barce ve } \\
\text { Teuchira: } 1 \text { tetradr. }\end{array}$ \\
\hline IGCH 1188 & Troas & MÖ Yak. 450 & 22 AR fr. & $\begin{array}{l}\text { Kyzikos: } 1 \text {; Lampsakos: } 2 \text {; } \\
\text { Kebren: } 11 \text {; Neandria: } 1 \\
\text { Skepsis: } 1 \text {; Tenedos: } 2 \text {; }\end{array}$ \\
\hline
\end{tabular}


Fariz ÖNCÜ

\begin{tabular}{|c|c|c|c|c|c|}
\hline & & & & & 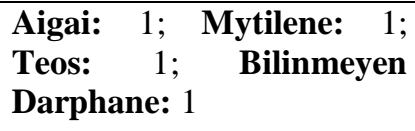 \\
\hline & IGCH 1189 & Batı Anadolu & MÖ Yak. 450 & $11 \mathrm{AR}$ & $\begin{array}{l}\text { Atina: } 1 \text { fr.; Klazomenai?: } \\
2 \text { fr.; Kolphon: } 5 \text { fr.; } \\
\text { Magnesia?: } 2 \text { fr. Teos: } 1 \text { fr. }\end{array}$ \\
\hline & IGCH 1190 & Batı Anadolu & MÖ Yak. 450 & $10+\mathrm{AR}$ & $\begin{array}{lll}\text { Kolophon: } & 6 & \text { tetartem.; } \\
\text { Teos: } 1 & \text { st., } 1 \text { fr.; } \\
\text { Bilinmeyen } & \text { darphane: } 1 \\
\text { fr. } & & \end{array}$ \\
\hline & IGCH 1254 & $\begin{array}{l}\text { Selimiye (Eski } \\
\text { Antalya, Side), } \\
\text { Pamphylia }\end{array}$ & MÖ Yak. 400 & $18+\mathrm{AR}$ & $\begin{array}{lcr}\text { Atina: } & 1 & \text { tetradr., } \\
\text { Korinthos: } & 1 & \text { st.; } \\
\text { Aspendos: } & 2+\text { double- } \\
\text { sigloi; Side: } & 12+\text { double } \\
\text { sigloi; Kitium, Azbaal: } 1 \\
\text { double-sigloi }\end{array}$ \\
\hline 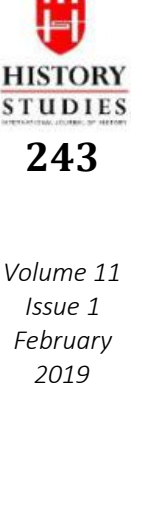 & IGCH 1255 & Kilikia & MÖ Yak. 400 & $1300+\mathrm{AR}$ & 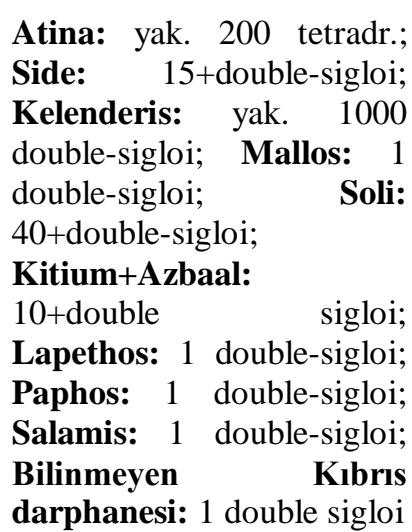 \\
\hline
\end{tabular}

Define bulunan bölgelerden biri olan Rhodos (IGCH 1185), MÖ 6. yüzyılın ikinci yarısından itibaren Akdeniz ticaretinin önemli kavşak noktalarından biri olagelir. Bunun en önemli kanıtlarından biri adada kullanılan ağırlık sitemlerinin gösterdiği çeşitliliktir. Ialyssos ${ }^{61}$ sikke üretiminde kendi yerel ağırlık sistemini kullanmasına rağmen, Lindos dönemin önemli ticari merkezlerinden Miletos'un ${ }^{62}$, Kamiros ise yine ticari faaliyetleriyle öne çıkan Aigina'nın ağırlık sistemini kullanır. ${ }^{63}$ Rhodos Adası'ndaki sikke ağırlık sisteminde görülen bu çeşitliliğin, adanın Batı Anadolu kıyıları, Ege adaları, Hellas, Mısır ve Yakındoğu'dan gelen yol güzergâhlarını birleştiren bir istasyon olma özelliğinden kaynaklandığı düşünülür. ${ }^{64}$ Sahip olduğu bu konumunun Rhodos'un zenginliğinde payı olduğu muhakkaktır. MÖ 480-408 tarihleri arasında Rhodos muhtemelen Atina'nın hegemonik yaklaşımından dolayı sikke üretimine ara verir. Bu durum Rhodos'un politik ve ekonomik ilişkilerini bu dönemde sikke dolaşımı üzerinden takip etmeyi engelleyen bir faktördür. Ancak gömü tarihi yaklaşık MÖ 450

\footnotetext{
${ }^{61}$ Ialyssos üretimi sikke örneği için bkz. Öncü, 2018, Levha VI, No. 126.

${ }^{62}$ Görkay, 1999, s. 198; Kraay, 1976, s. 35; T.H. Nielsen- V. Gabrielsen, "Rhodos", An Inventory of Archaic and Classical Poleis, Ed. M. H. Hansen-T.H.Nielsen, Oxford University Press, New York 2004, s. 1200, 1204.

${ }^{63}$ Görkay, a.g.e., 197-198; Kraay, 1976, s. 38; Nielsen - Gabrielsen, a.g.m., 1202. Kamiros ve Lindos sikkeleriyle ilgili örnekler için bkz. Öncü, 2018, Levha VI, No. 127-128.

${ }^{64}$ Kraay, a.g.e., 35 .
} 
olarak verilen ve kırk birden fazla değişik tür ve birimlerde gümüş sikke içeren Rhodos Definesi (IGCH 1185), bölgenin MÖ 5. yüzyılın ortalarında politik ve ekonomik bir kavşak noktası olarak konumunu korumuş olduğunu düşündürür. Bu define, Thrakia-Makedonya, Hellas, Batı ve Güneybatı Anadolu, Kıbrıs ve Kuzey Afrika yerleşimlerinin farklı darphanelerine ait sikkelerden oluşur (Tablo 6). Diğer definelerde olduğu gibi, bu sikkelerin dolaşımında ticari faktörlerin dışındaki başka etmenlerin de rolünün olması ihtimaller dâhilindedir. Özellikle, Atinalı General Kimon'un MÖ 460'ların ortasından MÖ 450'ye kadar Güneybatı Anadolu, Kıbrıs ve Mısır üzerine yaptığı seferler ${ }^{65}$, sikkelerin dolaşımında askerlerin rolünü en azından göz ardı etmemeyi gerektirir.

MÖ 5. yüzyıldaki ticari ilişkilerle doğrudan ilgili olup olmadığ belli olmadığ $\breve{g}_{1}$ halde, bölgelerarası politik ve ekonomik bağlantıların var olma imkânına dair ipucu veren başka defineler de vardır. Troia'da bulunan ve MÖ yaklaşık 450'ye tarihlenen definede (IGCH 1188) temsil edilen yirmi iki gümüş sikke fragmanının önemli bir bölümü (on beş tanesi) Troia bölgesindeki yerleşimlerin darphanelerin üretimleridir. Geriye kalanlar ise, Troia bölgesine fazla uzak olmayan Kyzikos, Aigai, Mytilene, Teos ve Tenedos gibi merkezlere ait sikkelerdir (Tablo 6).

Yine MÖ yaklaşık 450'ye tarihlenen bir definenin (IGCH 1183) bulunduğu Kolophon, Batı Anadolu'nun Akhaemenidler egemenliğindeki ekonomik faaliyetlerinin farklı bir yönünü sikkeler üzerinden gösteren merkezlerinden biridir. Ionia'nın iç kesiminde yer alan Kolophon, Pers gümüş siglosuna eşdeğer drahmi, tatraobolos ve obolos gibi farklı birimlerde gümüş sikkeler üretir. ${ }^{66}$ Pers ağırlık sisteminin kullanılması, muhtemelen bu polisin Sardeis'le kurduğu yakın ticari ilişkiden kaynaklanır. ${ }^{67}$ Aynı şekilde, bazı sikkelerini Pers siglosları ve Kolophon drahmileriyle eşdeğer ağırlıkta darp eden Erythrai ${ }^{68}$ da, bu iki merkezin dâhil olduğu ticari ağın içinde yer alıyor olmalıdır. Kolophon'da bulunan ve MÖ 450 tarihine atfedilen definenin (IGCH 1183) içindeki sikkelerin bölgesel dağılımı, bölgenin özellikle yakın merkezlerle ekonomik-ticari ilişkiler içinde olduğunu gösterir. Definede bulunan yüz yetmiş yedi gümüş ve üç elektron sikkenin önemli bir bölümü yakın bölgelerdeki darphanelerin üretimidir. Definede, Kolophon yetmiş dört, Teos ${ }^{69}$ otuz sekiz, Magnesia ${ }^{70}$ (?) yirmi alt1, Klazomenai ${ }^{71}$ on üç, Ephesos ${ }^{72}$ on, Miletos ${ }^{73}$ iki, Erythrai bir, Phokaia ${ }^{74}$ bir, Samos $^{75}$

\footnotetext{
${ }^{65}$ Plut. Kim. XII. 1-6; XIII. 1-2; XVI. 1; XVIII. 1-6; XIX. 1-2; Thuk. I. 104-110.

${ }^{66}$ Öncü, 2018, Levha IV, No. 63-67; L. Rubinstein, "Ionia", An Inventory of Archaic and Classical Poleis, Ed. M. H. Hansen-T. H. Nielsen, Oxford University Press, New York 2004, s. 1080.

${ }^{67}$ Balcer, 1991, 60.

${ }^{68}$ E. Babelon, Traité des monnaies grecques et romaines I-IV, Paris 1901, s. 303; Balcer, 1991, s. 60; P. Gardner, A History of Ancient Coinage. 700-300 B.C., Oxford 1918, s. 167-168; Head, 1911, s. 578; Öncü, 2018, Levha IV, No. 53-57.

${ }^{69}$ Teos, MÖ 6. yüzyılın ikinci yarısından itibaren Aigina ağırlık sisteminde çeşitli birimlerde sikke darp eder. Bkz. Kraay, 1976, s. 243; Balcer, 1991, s. 62-63. Teos sikkeleriyle ilgili örnekler için ayrıca bkz. Öncü, 2018, Levha IV, No 91-98.

${ }^{70}$ Attika ağırlık sisteminde Magnesia'da sikke darp eden Themistokles'e atfedilen sikke örnekleri için ayrıca bkz. Öncü, 2018, Levha II, No. 7-8; Tekin, 2008, s. 84.

${ }^{71}$ Kanatlı domuz protomunun üzerinde yer aldığı değişik birimlerdeki Klazomenai üretimi sikke örnekleri için bkz. Öncü, 2018, Levha IV, No. 58-62.

${ }^{72}$ Miletos ağırlık sistemine uygun darp edilen ( Tekin, 2008, s. 36) değişik birim ve tipteki Ephesos üretimi sikke örnekleri için bkz. Öncü, 2018, Levha IV, No. 48-52.

${ }^{73}$ Gümüş stater darbında 14.1 gramlık ağırlık sistemini kullanan Miletos, 1/96'ya kadar inen alt birimlerde sikkeler de darp eder. Miletos'a ait farklı birimlerde darp edilmiş sikke örnekleri için bkz. Öncü, 2018, Levha IV, No. 68-71.

${ }^{74}$ Phokaia'a ait farklı birimlerde darp edilmiş sikke örnekleri için bkz. Öncü, 2018, Levha IV, 72-79.

${ }^{75}$ Samos MÖ 600 civarında Euboia ağırlık sisteminde (yak. 17.2 gram), MÖ 6. yüzyılın son çeyreğinden sonra ise Miletos ağırlık sisteminde sikke darp etmeye başlar. Bkz. Kraay, 1976, s. 26, 36; Rubinstein, 2004, s. 1097; G.
} 
bir ve Pers kralları iki gümüş sikkeyle temsil edilirler. Geriye kalan az sayıdaki sikke ise, Kyzikos, Lampsakos, Kyme ve Karia'daki darphanelerin üretimidir ( Tablo 6). Kolophon sikkelerinin sayısal olarak baskın olduğu Batı Anadolu'daki farklı iki definede de (IGCH 1189 ve 1190) benzer bir yap1 görülür. IGCH 1189 'da Kolophon üretimi beş, Klazomenai üretimi iki, Magnesia üretimi iki, Teos üretimi iki ve Atina üretimi bir gümüş sikke temsil edilir (Tablo 6). IGCH 1190'da ise, Kolophon darphanesine ait altı ve Teos darphanesine ait bir sikke parçası ele geçer (Tablo 6). Sikkeler, politik ve ekonomik ilişkinin göstergelerinden biri olarak ele alındığında, MÖ 450 yıllarında ekonomik-politik bakımdan Kolophon'un da içinde yer aldığı Batı Anadolu'nun birbirine yakın birçok yerleşim merkezinin etkileşim içinde olduğu varsayılabilir.

Güney Anadolu kıyılarında Kilikia-Pamphylia sınırında bulunan ve MÖ 480'e tarihlendirilen define (IGCH 1177), bölgeye İtalya'nın güneyinden Hellas'a, ThrakiaMakedonya'dan Kuzey ve Güney Batı Anadolu'ya kadar farklı bölgeleri kapsayan darphanelerden gelen otuz sekiz gümüş sikkeyi barındırır (Tablo 6). Yine gömü yeri Selimiye (Side) olan ve MÖ yaklaşık 400'e tarihlendirilen define (IGCH 1254), çoğu yerel ve yakın çevre bölgelerindeki darphanelerin üretimi on sekizden fazla gümüş sikke barındırır. $\mathrm{Bu}$ sikkeler arasında Side'ye ait en az on iki ve Aspendos'a ait en az iki ve Kitium/Azbaal'a (Kıbrıs) ait bir sikkenin double-sigloi ağırlığında olması, Güney Anadolu bölgesi ve çevresinin bu dönemdeki ekonomik faaliyetlerinde Pers etkisinin işareti olarak kabul edilebilir (Tablo 6). Bu durum, yine, MÖ yaklaşık 400'e tarihlendirilen ve bin üç yüzden fazla gümüş sikke içeren bir diğer Kilikia definesindeki (IGCH 1255) sikkelerin dağılım ve nitelikleriyle daha net gözlemlenebilir. Yaklaşık iki yüz Atina tetradrahmisinin de yer aldığı bu definede geriye kalan sikkelerin tamamı Kilikia ve Kıbrıs darphanelerinin double-siglos ağırlık sistemiyle darp ettikleri üretimlerdir (Tablo 6).

Yine, gömü yeri Kyklad Adaları olan ve MÖ yaklaşık 500'e tarihlenen IGCH 6 Definesi (Tablo 6), gömü yeri Santorin (Thera) olan ve MÖ yaklaşık 500-490'a tarihlenen IGCH 7 Definesi (Tablo 6) ve gömü yeri Koumares/Thessalia olan ve MÖ yaklaşı 1 450'ye tarihlendirilen IGCH 21 Definesi ( Tablo 6), Batı ve Kuzey Batı Anadolu'daki Hellen polislerine ait sikkelerin MÖ 5. yüzyılın ilk yarısı boyunca Hellas'ın da dâhil olduğu bir coğrafyada dolaşımda olduklarını ve bu bölgeler arasında ekonomik faaliyetlerin devam ettiğini gösterir.

\section{Sonuç}

Anadolu coğrafyası MÖ 6. yüzyılın ikinci yarısının başlarından itibaren Akhaemenid/Pers İmparatorluğu'nun egemenliği altına girer. Perslerin Anadolu'daki hâkimiyeti iki asrı aşan bir döneme (MÖ yak. 547-330) yayılır. Bu dönemde Anadolu'nun değişik bölgelerindeki farklı sosyo-politik yapıları ve bölgesel ihtiyaçları göz önüne alarak idari bir sistem kuran Persler, siyasal egemenlikleri zarar görmediği sürece çoğunlukla mevcut yapıların devam etmesi ya da daha etkin bir düzeye ulaşması yönünde bir eğilim gösterirler. Bölgelerarası ekonomik ilişkiler ve uygulamalar da, aynı şekilde, Pers idaresinin yerel özellikleri dikkate alan yönetim anlayışına paralel bir gelişim çizgisi üzerinden ilerler. Bu durumun en önemli yansıması kendini sikke üretim ve dağılımında gösterir. Özellikle, Anadolu, Mısır, Suriye, İtalya, Makedonya ve Yunanistan'ın birçok yerinde ortaya çıkan sikke defineleri, Pesler döneminde (MÖ 6. ve 5. yüzyıllarda) bölgelerarası ekonomik-ticari ilişkilerle ilgili önemli veriler sunar.

Shipley, A History of Samos 800-188 B.C., Oxford, 1987, s. 87; Balcer, 1991, s. 60;Görkay, 1999, s. 196-197. Samos'a ait farklı birimlerde darp edilmiş sikke örnekleri için bkz. Öncü, 2018, Levha IV, 80-90. 
Sikke defineleri genel olarak ele alındığında, öncelikle Perslerin egemen oldukları bölgelerde çok sayıda merkezin sikke üretim faaliyetleri içinde olduğu görülür. Özellikle, Anadolu'nun kıyı kesimlerinde ele geçen ve daha çok MÖ 5. yüzyıla tarihlendirilen sikke definelerinin baskın yerel özelliği, bu sikkelerin bölgelerarası ticari faaliyetlerden ziyade yereldeki ihtiyaçları karşılamak için üretildiklerini gösterir. Definelerdeki sikkelerin bölgesel dağılımları, karışık definelerde bile yerel üretimlerin baskın bir karakterde olduğuna işaret eder. Aynı şekilde, Anadolu'nun kıyı kesimlerindeki komşu merkezler arasında sikke dolaşımının ve dolayısıyla ekonomik ilişkilerin daha yoğun olduğu, çok sayıda karışık sikke definesinin bölgesel dağılımından anlaşılabilir.

MÖ 5. yüzyıla tarihlendirilen sikke içerikleri ve bölgesel dağılımlarının dikkat çekici bir diğer noktası, Kyzikos ve Phokaia gibi Batı Anadolu, Karadeniz, Marmara ve Batı Akdeniz ticaretinde aktif oldukları bilinen merkezlerin üretimi olan elektron sikkelerin farklı definelerde ele geçmesidir. Kyzikos elektron sikkelerinin (kyzikene) Pers dareikoslarla olan değer eşitliği, her ne kadar bunların bazı bölgelerde asker maaşlarının ödenmesinde kullanılmış olabileceğini düşündürse de, bu sikkelerin önemli ticari faaliyetlerde kullanılmış olma olasılığı daha yüksektir. Dolayısıyla, Kyzikos sikkelerinin temsil edildiği defineler, MÖ 5. yüzyılda Karadeniz ve Marmara bölgesinde yer alan çok sayıda merkezin içinde olduğu yoğun bir ticari ilişkinin varlığına işaret eder.

Aynı şekilde, Suriye ve Mısır'da bulunan karışık defineler, MÖ 6. yüzyılın sonlarından başlayarak imparatorluğun bu bölgelerinin başta Thrako-Makedonya'daki merkezler olmak üzere, birçok bölgeyle ekonomik ilişkiler içinde olduğuna işaret eder. Ancak burada söz konusu bölgelerle ilgili bir noktayı gözden kaçırmamak gerekir; bu da MÖ 5. yüzyılın ortalarına kadar imparatorluğun bu bölgelerinde sikkenin sadece külçe olarak bir değer ifade ettiğidir. Bu yüzden, Suriye ve Mısır'daki definelerde bulunan ve farklı merkezlere atfedilen sikkelerin nominal değerleriyle ticari faaliyetlerde kullanılan bir değişim aracı olduğuna şüpheyle yaklaşmak gerekir. Ancak bu durum, söz konusu bölgelerdeki definelerde ele geçen sikkelerin bölgesel dağılımlarının bölgelerarası ticari ilişkilerin varlığına işaret etmediği anlamına da gelmez. Özellikle, Pers yönetiminin MÖ 520'lerden sonra vergileri gümüş formunda toplama talebi, gümüş madeni bakımından fakir olan imparatorluk bölgelerini bu madeni başka bölgelerden ticaret yoluyla temin etme çabası içine sokmuş olmalıdır. Böyle bir durumda, sikkenin gümüş külçe değeri üzerinden işleme tabi tutulan bir değişim aracı olarak bölgelerarası ticarette rol aldığı düşünülebilir.

$\mathrm{Bu}$ definelerde, aynı zamanda, Aigina, Khios, Atina, Korinthos, Phokaia, Miletos gibi ticari aktiviteleriyle de öne çıkan merkezlere ait sikkelerin mevcudiyeti, bu sikkelerin dolaşımında bölgelerarası ticaretin rolünü düşündüren diğer önemli verilerdir. $\mathrm{Bu}$ durum, başka merkezlerle birlikte yukarıda adı geçen bölgelerin sikkelerini barındıran Yunanistan ve İtalya'daki defineler için de geçerlidir.

Dolayısıyla, Perslerin Anadolu, Ege, Akdeniz ve Yakındoğu'nun büyük bir bölümünde egemen olduğu MÖ 6. ve 5. yüzyıllara tarihlendirilen sikke definelerinin içerikleri ve bölgesel dağılımları ölçüt alındığında, Pers hâkimiyetinin bölgelerarası ticari-ekonomik ilişkilerin devamı, hatta gelişimi yönünde olumlu bir etkisinin olduğu görülür. Bu durum, Aigina gibi gümüş madenleri açısından fakir olan ancak bölgelerarası yoğun ticari bağlantılarıyla bilinen merkezlere ait sikke ağırlık sistemlerinin, bu dönemde Batı ve Kuzey Batı Anadolu, Karadeniz ve Güney Ege'deki birçok yerleşim biriminde kullanılmasından da anlaşılır. 
Kaynakça

Alram, Michael, "The Coinage of the Persian Empire", The Oxford Handbook of Greek and Roman Coinage, Ed. William E. Metcalf, Oxford University Press, Oxford 2012, s. 6187.

Avram, A.- Hind, J. ve Tsetskhladze, G., "Black Sea Area", An Inventory of Archaic and Classical Poleis, Ed. M.H.Hansen-T.H.Nielsen, Oxford University Press, New York 2004, s. 924-974.

Babelon, E., Traité des monnaies grecques et romaines I-IV, Paris 1901.

Balcer, Jack M., "The Persian Occupation of Thrace 519-491 B.C. The Economic Effects", Actes du lle Congres international des Etudes du sud-est Européenes, Vol. 2, Athens 1972, s. 241-258.

Balcer, Jack M., “The East Greeks Under Persian Rule: A Reassessment”, Achaemenid History VI, Leiden 1991, s. 57-65.

Bing, J. D., A History of Kilikia During the Assyrian Period, Indiana University, Ph.D., Michigan 1968.

Bodenstedt, F., Phokäisches Elektron-Geld, von 600-326 v. Chr., Mainz 1976.

Borrell, H.P., "United Autonomous and Imperial Greek Coins" The Numismatic Chronicle and Journal of the Numismatic Society, Vol. 6, Ed. J. Y. Akerman, London, 1843/1844, s. 115-159.

Briant, Pierre, From Cyrus to Alexander: A History of the Persian Empire, Transl. by Peter T.Daniels, Eisenbrauns 2002.

Carradice, I. - Price, M., Helen Dünyasında Sikke, Çev: Oğuz Tekin, Homer Kitabevi, İstanbul 2001.

Colburn, Henry P., The Archaeology of Achaemenid Rule in Egypt, (Yayımlanmamış Doktora Tezi), Michigan Üniversitesi, 2014.

Cook, J. M., "The Rise of Achaemenids and Establishment of Their Empire", The Cambridge History of Iran, Vol.2, Cambridge 1996, s. 200-291.

Dandamaev, M. A. ve Lukonin, V. G., The Culture and Social Institutions of Ancient Iran, Cambridge University Press, Cambridge 1989.

DB (Dareios Bisitun-Behistan Yazıtı)

Kullanılan Metin ve Çeviri: Kent, R. G., Old Persian: Grammar, Texts, Lexion, American Oriental Society, New Haven 1953.

Dusinberre, Elspeth. R. M., Aspects of Empire in Achaemenid Sardis, Cambridge University Press, Cambridge 2003.

FGrHist Kullanılan Metin: Jacoby, F., Die Fragmente der Griechischen Historiker, Vols. I-XV, Leiden 1923-1958.

Figueira, Thomas, The Power of Money: Coinage and Politics in the Athenian Empire, University of Pennsylvania Press, Philadelphia 1998.

Flensted- Jensen, Pernille, "Karia", An Inventory of Archaic and Classical Poleis, M. H. Hansen -T. H. Nielsen (eds), Oxford University Press, New York 2004, s. 1108-1137.

Frye, R. N., The History of Ancient Iran, München, C.H. Beck'sche Verlagsbuchhandlung 1984.

Gardner, P., A History of Ancient Coinage. 700-300 B.C., Oxford 1918.

Görkay, Kutalmış, Batı Anadolu'ya Korinth ve Attika Siyah Figür Seramiğinin İthali, Dağılımı ve Değerlendirmesi, (Yayımlanmamış Doktora Tezi), Ankara Üniversitesi, Ankara 1999.

Hdt. (Herodotos, Historia) 
Kullanılan Metin ve Çeviriler: Herodotus, Vols. I-IV, Trans. A.D. Godley, LondonNew York 1975 (The Loeb Classical Library).

Head, B.V., Historia Numorum: A Manual of Greek Numismatics, Oxford 1911.

Herodotos/ Herodot Tarihi, Çev: Müntekim Ökmen, İstanbul 2002.

Hogarth, D.G., Excavations at Ephesus, London 1908.

Howgego, Christopher, Sikkelerin Işı̆̆ııda Eskiçağ Tarihi, Çev: Oğuz Tekin, Homer Kitabevi, İstanbul 2013.

IGCH Thompson, M. - Mørkholm, O.- Kraay, C.M., Inventory of Greek Coin Hoards, The American Numismatic Society, New York 1973.

Jenkins, G.K., Ancient Greek Coins, London 1990.

Kaya, Mehmet Ali, "Anadolu'da Pers Satraplıkları: Kuruluş, Yönetim ve Etnik Yapı", CEDRUS: Akdeniz Uygarliklarl Araştırma Dergisi, Vol. VI, Akdeniz Üniversitesi Akdeniz Uygarlıkları Araştırma Enstitüsü Yayınları, 2018, s. 59-179.

Kent, R. G., Old Persian: Grammar, Texts, Lexion, American Oriental Society, New Haven 1953.

Konuk, Koray, Karun'dan Karia'ya. Muharrem Kayhan Koleksiyonundan Erken Anadolu Sikkeleri, Ege Yayınları, İstanbul 2003.

Kraay, Colin M., Archaic and Classical Greek Coins, New York 1976.

Llewellyn L.-J. ve Robson, J. Ctesias' History of Persia. Tales of the Orient, Routledge, London-New York 2010.

Mitchell, Stephen, "Troas" An Inventory of Archaic and Classical Poleis, M. H. Hansen -T. H. Nielsen (eds), Oxford University Press, New York 2004, s. 1000-1017.

Nielsen, T. H. - Gabrielsen, V., "Rhodos", An Inventory of Archaic and Classical Poleis, M. H. Hansen-T. H. Nielsen (eds.), Oxford University Press, New York 2004, s. 11961210.

Nimchuk, C. L., "The 'Archers' of Darius: Coinage or Tokens of Royal Esteem?", Ars Orientalis, Vol. 32, Medes and Persians: Reflections on Elusive Empires (2002), S. Freer Gallery of Art, The Smithsonian Institution and Department of the Historyof Art, University of Michigan, 2002, s. 55-79.

Okan, Emre, Phokaia Arkaik Dönem Ticari Amforalar, (Yayımlanmamış Doktora Tezi), Dokuz Eylül Üniversitesi, İzmir 2011.

Öğün, Zeynep. Ç. ve Marcellesi, M.-C., "Réseaux d'échanges régionaux en Asie Mineure occidentale: l'apport des monnaies de fouilles", avec Z. Çizmeli-Öğün, dans Th. Faucher, M.-C. Marcellesi, O. Picard (ed.), Nomisma. La circulation monétaire dans le monde grec antique, BCH suppl. 53, Athènes 2011, s. 297-342.

Öncü, Fariz, M.̈̈. 6. ve 5. Yüzylllarda Achaemenid/Pers Imparatorluğu Yönetiminde Anadolu'da Ekonomik Durum, (Yayımlanmamış Doktora Tezi), Anakara Üniversitesi Sosyal Bilimler Enstitüsü, Ankara 2018.

Plut. Artak. (Plutarkhos, Artakserkses)

Kullanılan Metin ve CCeviri: Plutarch's Lives Vol. XI, Aratus, Artaxerxes, Galba and Otto, Transl. B. Perrin, London 2014. (The Loeb Classical Library).

Plut. Kim. (Plutarkhos, Kimon)

Kullanılan Metin ve Çeviri: Plutarch's Lives Vol. II, Themistocles and Camillus, Aristides and Cato, Major Cimon and Lucullus, Transl. B. Perrin, Cambridge Massachusetts- London 2014 (The Loeb Classical Library).

Plut. Per. (Plutarkhos, Perikles)

Kullanılan Metin ve Çeviri: Plutarch's Lives Vol. III, Pericles and Fabius

Maximus Nicias and Crassus, Transl. B. Perrin, London 2014 (The Loeb 


\author{
Classical Library). \\ Polyain. Strat. Polyainos, Strategemata) \\ Kullanılan Metin ve Çeviri: Polyaenus's Stratagems of War, Transl. by R. \\ Shepherds (1981), London.
}

Price, M. et al., "Reviewed Work(s): Archaic Greek Coinage. The Asyut Hoard", by Martin Price and NancyWaggoner, C. M. Kraay, The Journal of Helenic Studies, Vol. 97, 1977, s. 230-231.

Price, M. et al., "Reviewed Work(s): Archaic Greek Coinage. The Asyut Hoard", by Price Martin- NancyWaggoner, Reviewed by R. Ross Holloway, Gnomon, 50. Bd., H. 6, Oct., 1978, s. 597-600.

Psoma, S. E., "Choosing and Changing Monetary Standarts in the Greek World During the Archaic and Classical Periods", in: Edward M. Harris, David M. Lewis, Mark Woolmer (ed.), The Ancient Greek Ekonomy: Markets, Households and City-States, New York 2016, s. 90-115.

Ramage, A., "Golden Sardis", in: A. Ramage and P. T. Craddock (ed.), King Croesus' Gold, London, British Museum Press, 2000, s. 14-26.

HISTORY

STUDIES

249

Volume 11

Issue 1

February

2019

Ramage, A. - Ramage, N. H., Twenty-Five Years of Discovery at Sardis 1958-1983, United States of America: The National Endowment for the Humanities, 1983.

Rider, Georges L., La Naissance de la Monnaie: Pratiques Monétaires de I'Orient Ancien, Presses Universitaires de France, Paris 2001.

Rubinstein, L., "Ionia", An Inventory of Archaic and Classical Poleis, M. H. Hansen-T. H. Nielsen (ed.), Oxford University Press, New York 2004, s. 1053-1107.

Shipley, G., A History of Samos 800-188 B.C., Oxford 1987.

Tekin, Oğuz, Antik Nümismatik ve Anadolu (Arkaik ve Klasik Çağlar), Arkeoloji ve Sanat Yayınlar1, İstanbul 2008.

Tekin, Oğuz, Eski Yunan ve Roma Tarihine Giriş, İletişim Yayınları, İstanbul 2010.

Tekin, Oğuz, "Pers Döneminde Anadolu'da Para ve Ticaret", İçinde: Persler. Anadolu'da Kudret ve Görkem, K. İren-Ç. Karaöz-Ö. Kasar (ed.), Yapı Kredi Yayınları, 2017, s. 102-133.

Thompson, M. - Mørkholm, O.- Kraay, C.M., Inventory of Greek Coin Hoards, The American Numismatic Society, New York 1973.

Thuk. (Thukydides, Historiae)

Kullanılan Metin ve Çeviri: Thycydides Historiae, Vols. I-II, H.S. Jones- J.E. Powell (ed.), Oxford 1942.

Tuplin, Christopher, "The Changing Pattern of Achaemenid Persian Royal Coinage", P. Bernholz and R. Vaubel (ed.), Explaining Monetary and Financial Innovation, Financial and Monetary Policy Studies 39, DOI: 10.1007/978-3-319-06109-2-6, C Springer International Publishing Switzerland, 2014, s. 127-168.

Xen. Anab. ( Ksenophon, Anabasis)

Kullanılan Metin ve Çeviri: Anabasis, Vol. III, Boks: I-VII, Transl. C.L. Brownson, Cambridge-Massachusetts-London 2014 (The Loeb Classical Library). 